\title{
Towards a better understanding of the origins, chemical composition and aging of oxygenated organic aerosols: case study of a Mediterranean industrialized environment, Marseille
}

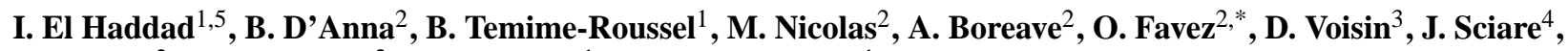 \\ C. George ${ }^{2}$, J.-L. Jaffrezo ${ }^{3}$, H. Wortham ${ }^{1}$, and N. Marchand ${ }^{1}$ \\ ${ }^{1}$ Aix-Marseille Université, CNRS, LCE FRE 3416, 13331 Marseille, France \\ ${ }^{2}$ Université Lyon 1, CNRS, UMR5256, IRCELYON, Institut de Recherches sur la Catalyse et l'Environnement de Lyon, \\ 69626 Villeurbanne, France \\ ${ }^{3}$ Universités Joseph Fourier-Grenoble 1-CNRS, UMR5183, Laboratoire de Glaciologie et Géophysique de l'Environnement, \\ 38402 Saint Martin d'Hères, France \\ ${ }^{4}$ Laboratoire des Sciences du Climat et de l'Environnement, CEA-CNRS-UVSQ-IPSL, 91191 Gif sur Yvette, France \\ ${ }^{5}$ Laboratory of Atmospheric Chemistry, Paul Scherrer Institut, 5232 Villigen PSI, Switzerland \\ *now at: INERIS, Parc Technologique Alata, BP2, 60550 Verneuil-en-Halatte, France
}

Correspondence to: I. El Haddad (imad.el-haddad@psi.ch) and N. Marchand (nicolas.marchand@univ-amu.fr)

Received: 6 July 2012 - Published in Atmos. Chem. Phys. Discuss.: 9 August 2012

Revised: 28 June 2013 - Accepted: 1 July 2013 - Published: 15 August 2013

\begin{abstract}
As part of the FORMES summer 2008 experiment, an Aerodyne compact time-of-flight aerosol mass spectrometer (cToF-AMS) was deployed at an urban background site in Marseille to investigate the sources and aging of organic aerosols (OA). France's second largest city and the largest port in the Mediterranean, Marseille, provides a locale that is influenced by significant urban industrialized emissions and an active photochemistry with very high ozone concentrations. Particle mass spectra were analyzed by positive matrix factorization (PMF2) and the results were in very good agreement with previous apportionments obtained using a chemical mass balance (CMB) approach coupled to organic markers and metals (El Haddad et al., 2011a). AMS/PMF2 was able to identify for the first time, to the best of our knowledge, the organic aerosol emitted by industrial processes. Even with significant industries in the region, industrial OA was estimated to contribute only $\sim 5 \%$ of the total OA mass. Both source apportionment techniques suggest that oxygenated OA (OOA) constitutes the major fraction, contributing $\sim 80 \%$ of OA mass. A novel approach combining AMS/PMF2 data with ${ }^{14} \mathrm{C}$ measurements was applied to identify and quantify the fossil and non-fossil precursors of this fraction and to explicitly assess the related uncertainties.
\end{abstract}

Results show with high statistical confidence that, despite extensive urban and industrial emissions, OOA is overwhelmingly non-fossil, formed via the oxidation of biogenic precursors, including monoterpenes. AMS/PMF2 results strongly suggest that the variability observed in the OOA chemical composition is mainly driven in our case by the aerosol photochemical age. This paper presents the impact of photochemistry on the increase of OOA oxygenation levels, formation of humic-like substances (HULIS) and the evolution of $\alpha$-pinene SOA (secondary OA) components.

\section{Introduction}

Organic aerosol (OA) is composed of a highly dynamic mixture governed by multiple emission sources, reversible phase partitioning, and chemical transformations and removal (Donahue et al., 2009; Hallquist et al., 2009; Jimenez et al., 2009). The pathways by which OA most significantly accumulates and evolves in the atmosphere have been under close scrutiny of late. The traditional perspective has been that $\mathrm{OA}$ is either directly emitted by combustion sources (primary OA, POA) or formed by secondary 
processes (secondary OA, SOA) via the oxidation of biogenic and anthropogenic volatile organic compounds (VOC). However, a major challenge for our understanding of OA is the exceedingly reactive nature of organic compounds in the atmosphere, having gas-phase lifetimes against $\mathrm{OH}$ radicals of five to eight hours under typical daytime conditions (e.g., Atkinson and Arey, 2003 and references therein). As a result, once compounds that make up OA are emitted or formed in the atmosphere, they will typically undergo one or two generations of oxidation in one day. Combined with the myriad of primary compounds and SOA precursors introduced in the atmosphere, ongoing aging generates an immensely complex mixture of organic compounds whose chemical characteristics significantly differ from those of the parent precursors. Recent aerosol mass spectrometer (AMS, Aerodyne) measurements of bulk OA (Jimenez et al., 2009 and references therein) and the detection of substantial amounts of VOC oxidation products in particle phase (Kleindienst et al., 2007 and references therein) underline the strong influence of aging processes on the bulk atmospheric aerosol. They reveal the highly oxidized nature of $\mathrm{OA}(\mathrm{O}: \mathrm{C} \sim 0.3-1)$, comprising significant amounts of multifunctional compounds (e.g., tricarboxylic acids, Szmigielski et al., 2007), including humiclike substances (HULIS) that contribute up to $50 \%$ of OC mass (Baduel et al., 2009, 2010). However, current state-ofthe-art models (e.g., chemical transport models) are unable to explain the burden and oxygenation levels of such compounds, especially in urban environments and highly aged air masses (e.g. Volkamer et al., 2006). This discrepancy highlights a remaining fundamental gap in our understanding of the predominant precursors and formation and aging pathways of oxygenated OA (OOA).

Recent studies have therefore targeted a number of techniques to characterize both primary and secondary OA. One of the traditional approaches to investigate OA sources is the chemical mass balance (CMB, e.g., Watson et al., 1998), which draws upon highly specific organic markers (e.g., hopanes for vehicular emissions) to assess the contribution of emissions from major primary sources, e.g., gasoline vehicles, diesel vehicles and biomass burning. The residual OA that is not attributed to any primary source considered in the model is commonly regarded as SOA. More recently, positive matrix factorization techniques (PMF2) have been applied to AMS measurements to delineate OA by a number of factors subsequently linked to emission sources or formation processes. Widely reported factors include those related to primary emissions, such as hydrocarbon-like OA (HOA), biomass smoke (BBOA) and cooking emissions (COA) and factors characteristic of oxygenated aerosol (OOA), commonly related to SOA (Jimenez et al., 2009 and references therein). The approach is unable to identify the main OOA precursors, but often apportions the latter fraction according to its volatility and oxygenation levels. This yields a moderately oxygenated fraction (SVOOA) attributed to semivolatile species due to its correlation with particulate nitrate, and a more oxygenated fraction (LVOOA) attributed to lowvolatile species due its correlation with particulate sulfate (Jimenez et al., 2009). This analogy is consistent with measurements of ambient OA volatility (Cappa and Jimenez, 2010). While some studies tentatively related SVOOA to specific precursors, including for example terpenes (Slowik et al., 2010), the chemical composition, important gas-phase precursors and formation pathways of LVOOA remain ambiguous.

The FORMES project (Favez et al., 2010; El Haddad et al., 2011a, b) included a summer field measurement campaign (July 2008) at an urban background site in Marseille (France's second largest city and the largest port in the Mediterranean). The campaign's aim was to investigate the major sources of OA and its atmospheric aging in an urban industrialized environment, highly impacted by photochemistry. In previous works (El Haddad et al., 2011a, b), we have presented filter based measurements, including organic molecular markers, metals and radiocarbon content $\left({ }^{14} \mathrm{C}\right)$. Applying a chemical mass balance $(\mathrm{CMB})$ approach, we found that the OA was dominated by SOA, which based on ${ }^{14} \mathrm{C}$ analyses was suggested to be heavily influenced by biogenic sources. A thorough investigation of the data suggested that oxidation products of biogenic precursors could not explain the levels nor the variability of the observed SOA, implying a significant contribution of missing SOA precursors or unknown formation pathways. In particular, the role of aging in the formation and evolution of SOA remained unclear. Here, we utilize the online AMS (aerosol mass spectrometer) and HS-PTR-MS (high sensitivity proton transfer reaction mass spectrometer) measurements conducted during FORMES-2008 to better characterize the chemical composition, sources and aging of OA, with a special focus on the oxygenated fraction (OOA). Source apportionment results using positive matrix factorization (PMF2) are first presented and compared with the previous CMB results. The OOA precursors, chemical composition and the influence of oxidative aging therein are then investigated to elucidate the main processes driving the observed SOA levels and variability.

\section{Materials and methods}

\subsection{Sampling location and general conditions}

Sampling for the FORMES 2008 summer field campaign was conducted from 30 June to 14 July 2008, at an urban background site in the downtown park "Cinq Avenues", Marseille $\left(43^{\circ} 18^{\prime} 20^{\prime \prime} \mathrm{N}, 5^{\circ} 23^{\prime} 40^{\prime \prime} \mathrm{E}, 64 \mathrm{~m}\right.$ a.s.l.). France's second most populous city ( $\sim 1$ million inhabitants), Marseille is the most important Mediterranean Sea port and a major transportation hub for the region. It is also in the immediate vicinity of the large petrochemical and industrial area of Fos-Berre, located $40 \mathrm{~km}$ northwest of the metropolitan city (Fig. 1). Significant 


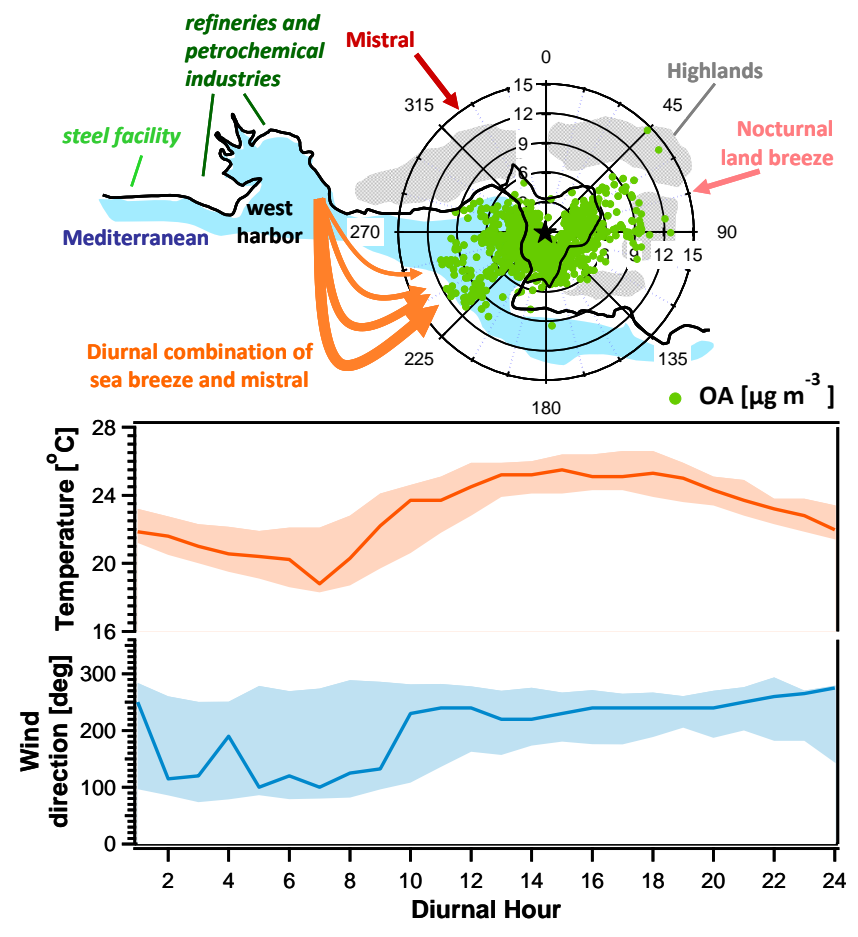

Fig. 1. Marseille's topography, wind circulation and general conditions encountered during the measurement period. The map (upper panel) shows the sampling site (black star) in the downtown park "Cinq Avenues" with respect to the major industries. The wind rose shows OA concentrations measured by the AMS as a function of wind direction. Lower panel shows the diurnal profiles for the temperature and wind directions. Solid lines denote median profiles and dashed areas denote P25-P75 ranges.

heavy industry in the area includes petrochemical refineries, shipyards, steel works, and coke production plants.

In addition to synoptic air masses arriving from the Atlantic and the Mediterranean (see Fig. S1, Supplement), two regional wind patterns are common during the summer in Marseille: (i) the Mistral and (ii) a diurnal sea and land breeze cycle. The Mistral is a strong, regional northwesterly wind $\left(310-350^{\circ}\right)$, which blows from the lower Rhone River valley toward the Mediterranean Sea (Fig. 1). The westerly sea breeze $\left(320-370^{\circ}\right)$ and easterly land breeze (50$100^{\circ}$ ) are local winds prevailing during light Mistral periods. These stem from the surrounding topography of Marseille, bordered by the Mediterranean from the southwest and enclosed from the north, east and south by mountain ranges up to $\sim 700 \mathrm{~m}$ a.s.l. (Fig. 1). During periods of light Mistral, typically at night (e.g., 4, 10, and 11 July), and sea breeze episodes in early mornings (e.g., 30 June and 5, 10, and 12 July), the metropolitan area of Marseille was frequently influenced by the outflow of Fos-Berre. Photochemical processing of industrial emissions from this region during periods of sea breeze induces the formation of fresh secondary pollutants, including ozone, sulfate and SOA (El Haddad et al., 2011b), whose concentrations increase over the course of a day. These components are then diluted with the increase of the boundary layer height or transported away from Marseille towards sparsely populated northern regions where they mix and age further. At night the land breeze develops, bringing these further aged air masses back to Marseille (Fig. 1). This cycle may persist for several days, resulting in the accumulation and continuous aging of air pollutants and thus the highest levels of organic aerosol during the measurement period (see wind rose in Fig. 1).

\subsection{Particle sampling and online analyses}

Time-resolved online measurements of particle composition were performed using a compact time-of-flight (c-TOF, Tofwerk) aerosol mass spectrometer (AMS, Aerodyne Inc., USA) and an organic carbon/elemental carbon (OC/EC) Sunset field instrument (Sunset Laboratory, Forest Grove, OR, USA; Bae et al., 2004). The AMS operating principles, calibration procedures, and analysis protocols are described in detail elsewhere (e.g., Drewnick et al., 2005; Canagaratna et al., 2007). The instrument provides quantitative size-resolved mass spectra of the non-refractory $\mathrm{PM}_{1}$ components, empirically defined as vaporizable species over a $1 \mathrm{~s}$ time interval at $600^{\circ} \mathrm{C}$ and $10^{-7}$ torr. These include organic aerosol (OA) and ammonium nitrate and sulfate $\left(\mathrm{NH}_{4}^{+}, \mathrm{NO}_{3}^{-}\right.$and $\left.\mathrm{SO}_{4}^{2-}\right)$. The Sunset (operating at $8 \mathrm{~L} \mathrm{~min}^{-1}$ ) collected hourly $\mathrm{PM}_{2.5}$ measurements of EC and OC. The former is a refractory fraction and hence not measurable by the AMS.

An important consideration in the quantitative analysis of AMS data is the collection efficiency (CE) related to particle bounce. $\mathrm{CE}$ was estimated through comparison of the aggregate mass of $\mathrm{OA}, \mathrm{NH}_{4}^{+}, \mathrm{NO}_{3}^{-}$and $\mathrm{SO}_{4}^{2-}$ from AMS and EC from Sunset with volume distributions from a colocated SMPS (scanning mobility particle sizer, L-DMA and CPC5403, GRIMM). We assessed the CE for the FORMES campaign as $0.65 \pm 0.14$ ( $22 \%$ uncertainty), comparable to values typically found for ambient aerosol $(\sim 0.5$, Middlebrook et al., 2012). Data presented below are all corrected for CE.

For offline aerosol analyses, $\mathrm{PM}_{2.5}$ particles were collected using high volume samplers (HiVol, Digitel DA80) operating at a flow rate of $30 \mathrm{~m}^{3} \mathrm{~h}^{-1}$. Particle sampling was performed on a $12 \mathrm{~h}$ basis (05:30 to 17:30 UT, and 17:30 to 05:30 UT, 30 total number samples) onto $150 \mathrm{~mm}$-diameter quartz fibre filters (Whatman QMA), pre-heated at $500^{\circ} \mathrm{C}$ during $3 \mathrm{~h}$. Samples were then stored at $-18^{\circ} \mathrm{C}$ in aluminium foil and sealed in polyethylene bags until analysis. Six field blank samples were also prepared following the same procedure. PM was also collected on a $24 \mathrm{~h}$ timescale onto preheated $25 \mathrm{~mm}$-diameter quartz filters, utilizing a Dekati 13stage low pressure cascade impactor (LPI) at a flow rate of $30 \mathrm{~L} \mathrm{~min}^{-1}$, for size resolved EC/OC analysis. 


\subsection{Gas measurements}

In addition to particle sampling, VOCs were also measured using HS-PTR-MS (high sensitivity proton transfer reaction mass spectrometer, IONICON Analytik $\mathrm{GmbH}$, Lindinger et al., 1998). In the HS-PTR-MS, $\mathrm{H}_{3} \mathrm{O}^{+}$ions, generated by a cathode discharge in water vapor, ionize trace gases with a higher proton affinity than water; the resulting ions are detected with a quadrupole mass spectrometer. This soft ionization technique causes relatively little fragmentation, such that measured fragments are often parent ions and can frequently be related to specific VOCs. The PTR-MS was operated at standard conditions, i.e., using a $2.25 \mathrm{mbar}$ ion drift pressure and a drift field intensity of $130 \mathrm{Td}$. These conditions prevent excessive clustering and VOC-water adducts formation. Isomers, such as isoprene oxidation products (methacrolein, MACR and methyl vinyl ketone, MVK) or monoterpenes cannot be distinguished by the HS-PTR-MS. The species measured here comprise methanol $\left(\mathrm{m} / 233, \mathrm{CH}_{5} \mathrm{O}^{+}\right)$, acetone $\left(\mathrm{m} / \mathrm{z} 59, \mathrm{C}_{3} \mathrm{H}_{7} \mathrm{O}^{+}\right)$, acetic acid $\left(\mathrm{m} / \mathrm{z} 61, \mathrm{C}_{2} \mathrm{H}_{5} \mathrm{O}_{2}^{+}\right)$, isoprene $\left(\mathrm{m} / z 69, \mathrm{C}_{5} \mathrm{H}_{9}^{+}\right), \operatorname{MACR}+\mathrm{MVK}\left(\mathrm{m} / z 71, \mathrm{C}_{4} \mathrm{H}_{7} \mathrm{O}^{+}\right)$, benzene $\left(\mathrm{m} / z 79, \mathrm{C}_{6} \mathrm{H}_{7}^{+}\right)$, toluene $\left(\mathrm{m} / \mathrm{z}, 93, \mathrm{C}_{7} \mathrm{H}_{9}^{+}\right)$and monoterpenes $\left(\mathrm{m} / \mathrm{z} 137, \mathrm{C}_{10} \mathrm{H}_{17}^{+}\right)$. Despite the presence of numerous interferences and isomers, previous studies have shown that HS-PTR-MS measurements for these species compares well against alternative techniques (see for example de Gouw and Warneke, 2007; Vlasenko et al., 2009). Fifteen min-averaged $\mathrm{NO}_{\mathrm{X}}, \mathrm{O}_{3}$ and $\mathrm{SO}_{2}$ concentrations were also determined by the standard equipment of the air quality monitoring network.

\subsection{Offline analyses}

Data presented here heavily rely on offline analysis results, which are comprehensively discussed in El Haddad et al. (2011a, b). Therefore, a technical description of the analytical methods is outlined in the Supplement (Sect. S3); for more detail the reader can also refer to the method sections in El Haddad et al. (2011a, b). We also present in the Supplement (Sect. S4) a comparison between online AMS and offline filter based measurements for $\mathrm{OA}$ and $\mathrm{SO}_{4}^{2-}$. The comparison shows that while a very good agreement between both methods for $\mathrm{SO}_{4}^{2-}$ is observed (providing additional support for the determined CE), filter OA might be associated with substantial adsorption artefacts, up to $28 \%$.

Besides online OC/EC measurements, we also analyzed the carbonaceous content of high volume $150 \mathrm{~mm}$ diameter filters and LPI $25 \mathrm{~mm}$ diameter filters using a thermo-optical transmission method on a Sunset Lab analyzer, following both NIOSH (Schmid et al., 2001) and EUSAAR-2 (Cavalli et al., 2010) protocols. For the analyses of major ions $\left(\mathrm{NH}_{4}^{+}, \mathrm{SO}_{4}^{2-}, \mathrm{NO}_{3}^{-}\right)$, water-soluble organic carbon and water-soluble humic-like substances (HULIS), sample fractions of $11.34 \mathrm{~cm}^{2}$ from high volume samples were extracted into $15 \mathrm{~mL}$ ultrapure Milli-Q water by $30 \mathrm{~min}$ short
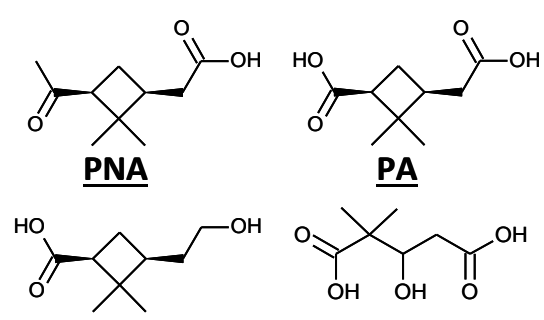<smiles>O=C(O)CC(O)CC(=O)O</smiles><smiles>CC(C)(C(=O)O)C(O)CC(=O)O</smiles><smiles>CC(=O)CC(CC(=O)O)C(C)=O</smiles><smiles>CC(=O)C(CCC(=O)O)CC(=O)O</smiles>

A5

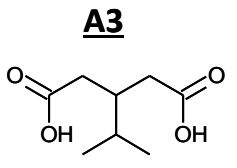

$\underline{A 6}$

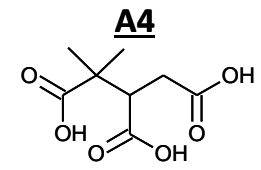

A7
Fig. 2. $\alpha$-pinene SOA markers consisting of 9 oxidation products: 3-hydroxyglutaric acid (A1), 3-(2-hydroxyethyl)2,2-dimethylcyclobutane carboxylic acid (A2), 3-hydroxy4,4-dimethylglutaric acid (A3), 3-acetylglutaric acid (A4), 3-acetyladipic acid (A5), and 3-isopropylglutaric acid (A6) and 3-methyl-1,2,3-butanetricarboxylic (A7), pinic acid (PA) and pinonic acid (PNA).

vortex agitation (Piot et al., 2012). HULIS analysis was performed following the method described in Baduel et al. (2009, 2010), involving an extraction by adsorption onto DEAE resin (GE Healthcare ${ }^{\circledR}$, HiTrapTM DEAE FF, $0.7 \mathrm{~cm}$ ID $\times 2.5 \mathrm{~cm}$ length) and subsequent quantification with an OI Analytical 700 total organic carbon analyzer. Fifty elements were measured using an inductively coupled plasma mass spectrometer (Agilent 7500ce) following complete dissolution of filter aliquots in a mixture of high-purity concentrated $\mathrm{HF}$ and $\mathrm{HNO}_{3}$. As fully described in El Haddad et al. (2011a, b) and in the Supplement, a chemical derivatization/gas chromatography-mass spectrometry (GCMS) approach was used to quantify primary and secondary organic markers, including $\alpha$-pinene oxidation products $-\mathrm{a}$ major focus of this study. The chemical structure of these compounds is shown in Fig. 2. Finally, ${ }^{14} \mathrm{C}$ content of total carbonaceous aerosol $(\mathrm{TC}=\mathrm{OC}+\mathrm{EC})$ was measured using ARTEMIS accelerator mass spectrometry, following a complete combustion of total carbon at $850{ }^{\circ} \mathrm{C} .{ }^{14} \mathrm{C}$ measurements offer a direct and quantitative discrimination between fossil and non-fossil carbon (Szidat, 2009; Hodzic et al., 2010), as ${ }^{14} \mathrm{C}$ is depleted in fossil emissions (POA and SOA). The non-fossil fraction in TC was determined as the ratio of ${ }^{14} \mathrm{C} /{ }^{12} \mathrm{C}$ in aerosol sample compared to ${ }^{14} \mathrm{C} /{ }^{12} \mathrm{C}$ in the NBS (National Bureau of Standards) oxalic acid standard (NIST-SRM-4990B). ${ }^{14} \mathrm{C}$ results are discussed in Sect. 4. 


\subsection{Source apportionment}

\subsubsection{AMS/PMF2 analyses}

AMS OA mass spectra were analyzed by Positive Matrix Factorization, PMF2 (Paatero and Tapper, 1994; Lanz et al., 2007; Ulbrich et al., 2009), a receptor modeling technique in which the organic mass spectra time series $(X)$ is expressed as a linear combination of a set of characteristic factor profiles $(F)$ and their time-dependent intensities $(G)$, such that

$\mathbf{X}=G F+\mathbf{E}$.

In the matrix Eq. (1), $\mathbf{E}$ is the residual matrix, defined as the difference between the data matrix $(\mathbf{X})$ and the fitted solution $(G F)$. PMF2 requires as inputs the data matrix $(\mathbf{X})$ and the associated uncertainty matrix $(\mathbf{S})$, both obtained here from the AMS data-analysis software, Squirrel. Uncertainties were calculated in Squirrel based on Allan et al. (2003) and modified following the recommendations of Ulbrich et al. (2009). The input matrices ( $\mathbf{X}$ and $\mathbf{S}$ ) are composed in our case of 4043 data points with $276 \mathrm{~m} / \mathrm{z}$.

A key consideration for PMF analysis is the number of factors selected by the user. As currently no methodical and completely objective approach exists for choosing the right number of factors, this selection must be evaluated through comparisons of factor and external tracers' time series and the analyses of factor mass spectra and diurnal patterns. First, we examined a 3-factor solution that yielded factors interpreted as hydrocarbon-like organic aerosol (HOA), semi-volatile oxygenated organic aerosol (SVOOA) and low volatility oxygenated organic aerosol (LVOOA), designations resulting from examining the factors' mass spectra. The addition of one more factor revealed the influence of industrial emissions (see Sect. 3.1), an expected aerosol source in the region (El Haddad et al., 2011a). Higher order solutions were then explored but could not be successfully interpreted. A 5-factor solution introduced a third OOA factor and altered the mass spectra and time series of SVOOA, LVOOA and HOA. The additional factor did not aid the interpretation of the dataset, as its time series strongly correlates with those of the other two OOA factors and hence could not be explicitly ascribed to a distinct source or process. Further, the 5-factor solution exacerbated the correlation between PMF2factors and external data, resulting in some ambiguity in clearly attributing the other 4 factors to specific sources and processes. These features seem to be consistent with factor mixing/splitting, identified by Ulbrich et al. (2009) as an indication of excessive number of factors. Given the lack of improvement in the understanding of the aerosol source apportionment and the absence of external tracers supporting the additional OOA factor in the 5-factor solution, the 4-factor solution was considered optimal and therefore discussed below.
For the 4-factor solution, matrix rotations were explored by varying the FPEAK parameter (rotational freedom parameter) from -2.0 to 2.0, as discussed in the Supplement (Sect. S5). The selected solution is obtained at FPEAK $=0$ and very little variability in the factor's time series and mass spectra is observed for solutions at FPEAK between 0 and 1 (Fig. S4, Supplement). The possibility of local minima in the solution space was considered by initiating the PMF2 algorithm from 60 random starting points (seeds $=[0-59]$ ). All convergent solutions were found to be consistent with the solution presented below at seed $=0$, an indication of the robustness of the chosen solution.

\subsubsection{CMB analysis}

In El Haddad et al. (2011a), we presented a chemical mass balance (CMB, Watson et al., 1998) approach based on organic markers and metals to apportion the primary sources of $\mathrm{PM}_{2.5}$ organic carbon (OC) in Marseille, with a special focus on industrial emissions. CMB results are compared here with AMS/PMF2 outputs (Sect. 3.2). Primary sources considered in the $\mathrm{CMB}$ comprise vehicular emissions and industrial emissions, the latter representing an aggregate of three processes: coke production, metal smelting, and shipping/oil burning. In order to compare between CMB results and AMS/PMF2 results, OA from primary emissions was calculated by applying an OM-to-OC ratio of 1.2 (based on Aiken et al., 2008) to the corresponding primary OC mass apportioned by CMB. CMB-SOA is indirectly inferred as the difference between the primary OA modeled by the $\mathrm{CMB}$ and the total OA, determined by scaling the measured $\mathrm{OC}$ by an OM-to-OC ratio of 1.67 (calculated by comparing AMSOA with LPI OC measurements; see Sects. S3 and S4 in the Supplement). Further information regarding the CMB analysis can be found in the Supplement (Sect. S6) and in El Haddad et al. (2011a).

\subsubsection{Estimation of $\alpha$-pinene SOA contributions}

Contributions of $\alpha$-pinene SOA to ambient OA was estimated following the marker-based approach developed by Kleindienst et al. (2007). This approach consists of converting the measured concentrations of marker compounds derived from a given precursor hydrocarbon (hydrocarbon, $\mathrm{HC}$ ) into a SOA concentration in $\mu \mathrm{g} \mathrm{m}^{-3}$ (SOA $\mathrm{SC}_{\mathrm{HC}}$ ), using the laboratory-generated mass fractions of the same markers $\left(f_{\mathrm{SOA}, \mathrm{HC}}\right)$ determined by Kleindienst et al. (2007). SOA $\mathrm{HC}$ can be subsequently calculated as follows:

$\mathrm{SOA}_{\mathrm{HC}}=\frac{\sum_{i}^{m} M_{i}}{f_{\mathrm{SOA}, \mathrm{HC}}}$

where $M_{i}$ is the concentration of the marker $i$ and $m$ is the total number of markers derived from the hydrocarbon $\mathrm{HC}-$ here $\mathrm{HC}$ is $\alpha$-pinene. For the apportionment of $\alpha$-pinene SOA contributions, pinonic acid, pinic acid and 


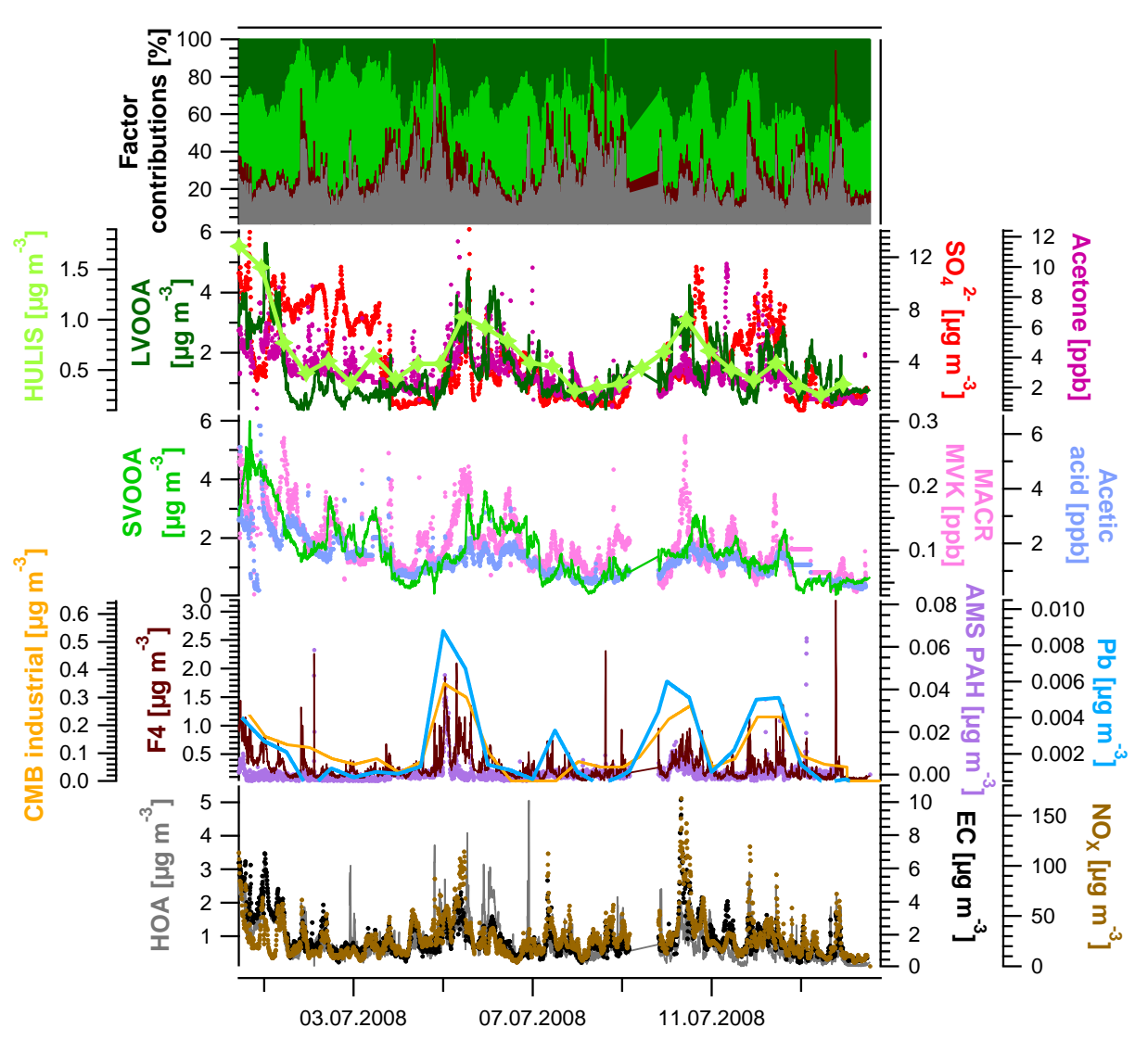

Fig. 3. Time series for AMS/PMF2 4-factors solution (FPEAK $=0, \mathrm{SEED}=0$ ) compared with selected tracers $\mathrm{NO}_{\mathrm{X}}$ and $\mathrm{EC}$ for $\mathrm{HOA}$, $\mathrm{Pb}$, AMS-PAHs, CMB industrial OA for F4, acetic acid (PTRMS, $m / z, 61, \mathrm{C}_{2} \mathrm{H}_{5} \mathrm{O}_{2}^{+}$) and $\mathrm{MACR}+\mathrm{MVK}\left(\mathrm{PTRMS}, m / z, 73, \mathrm{C}_{4} \mathrm{H}_{7} \mathrm{O}^{+}\right.$) for SVOOA, and acetone (PTRMS, $m / z, 59, \mathrm{C}_{3} \mathrm{H}_{7} \mathrm{O}^{+}$), HULIS and $\mathrm{SO}_{4}^{2-}$ for LVOOA. The upper-panel shows factors contributions time series.

A1-A7 (Fig. 2) were considered as markers and a $f_{\mathrm{SOA}, \mathrm{HC}}$ factor of $0.168 \pm 0.08$ was used (Kleindienst et al., 2007).

\section{Source apportionment results}

\subsection{Interpretation of AMS/PMF2 results}

As noted above, we selected as the best representation of the data the 4-factor PMF2 solution, results of which are interpreted in this section and compared with CMB results in Sect. 3.2. Amongst the four identified factors, three are commonly reported (e.g., Jimenez et al., 2009 and references therein), identified as HOA, SVOOA and LVOOA, where HOA is representative of primary, hydrocarbon-like emissions, and SVOOA and LVOOA both represent oxidized organic aerosol, with the latter considered to be generally more oxygenated than the former. These designations are initially based on the factors mass spectra (see Fig. S5, Supplement), which exhibit analogous patterns as those obtained in previous studies (Table 1). The factors identification is then confirmed by examining their correlation with time series of external tracer species (Fig. 3) and their diurnal profiles (Fig. 4).

The HOA, typically associated with traffic emissions, is characterized by a prominent diurnal pattern with increasing contributions during rush hours (Fig. 4). As was found in previous studies (Lanz et al., 2007; Ulbrich et al., 2009; Slowik et al., 2010; Sjostedt et al., 2011), HOA exhibits rather strong temporal correlations with primary vehicular emissions tracers, such as EC $(R=0.68$, Table 1$)$ and $\mathrm{NO}_{\mathrm{X}}$ $(R=0.54$, Table 1$)$. Note that some unexplained variability between HOA and these tracers remains. This might partially be caused by changes in vehicle emission profiles (e.g., diesel vs. gasoline), as for example an equivalent correlation coefficient is obtained between $\mathrm{EC}$ and $\mathrm{NO}_{\mathrm{X}}(R=0.71)$. A further inspection of the relationship between HOA and EC seems to suggest that other factors also influence the dynamics of HOA. This is shown in Fig. 4 through the diurnal profile of the HOA/EC ratio (see also Fig. S7, Sect. S8, Supplement), where it can be seen that this ratio, which for an average fleet is expected to remain constant throughout the day, periodically rises above values reported for vehicular emissions (HOA/EC 0.4, e.g., Chirico et al., 2011 and 
Table 1. Pearson correlation coefficients, $R(P \leq 0.05)$ : (a) between factor's mass spectra and reference mass spectra drawn from previous ambient, emission and chamber studies and (b) between factors time series and external markers time series. $R$ coefficients greater than 0.5 are marked in bold typeface.

\begin{tabular}{|c|c|c|c|c|}
\hline & $\mathrm{HOA}$ & SVOOA & LVOOA & F4 \\
\hline \multicolumn{5}{|c|}{ (a) Correlation with reference spectra } \\
\hline HOA (Zhang et al., 2005) & 0.97 & 0.57 & 0.16 & \\
\hline Diesel bus exhaust (Canagaratna et al., 2004) & 0.96 & 0.66 & 0.25 & \\
\hline SOA $\alpha$-pinene (Bahreini et al., 2005) & 0.81 & 0.96 & 0.59 & \\
\hline Aged Rural (Alfarra et al., 2004) & 0.55 & 0.79 & 0.94 & \\
\hline OOA_I (Lanz et al., 2007) & 0.41 & 0.71 & 0.99 & \\
\hline \multicolumn{5}{|c|}{ (b) Correlation with external markers } \\
\hline EC & 0.68 & 0.48 & 0.49 & 0.52 \\
\hline $\mathrm{NO}_{X}$ & 0.54 & 0.07 & 0.32 & 0.55 \\
\hline$\alpha$-pinene SOA & 0.40 & $0.66 \mid 0.74 *$ & 0.47 & 0.05 \\
\hline MACR+MVK & 0.43 & 0.61 & 0.42 & 0.33 \\
\hline acetic acid & 0.40 & 0.72 & 0.35 & 0.25 \\
\hline acetone & 0.45 & 0.52 & 0.59 & 0.29 \\
\hline HULIS & 0.44 & 0.69 & 0.82 & 0.28 \\
\hline Sulfate & 0.24 & 0.22 & 0.60 & 0.13 \\
\hline CMB-industrial OA & 0.26 & 0.28 & 0.13 & 0.63 \\
\hline AMS-PAHs & 0.10 & 0.09 & 0 & 0.52 \\
\hline $\mathrm{Pb}$ & 0.23 & 0.30 & 0.13 & 0.71 \\
\hline
\end{tabular}

* For the correlation between SVOOA and $\alpha$-pinene SOA, 2 coefficients are calculated considering for the first all data points $(R=0.66)$ and excluding for the second data points where the site was downwind of industrial emissions $(R=0.74)$, as shown in Fig. 9.

references therein). Such elevated HOA/EC periods, mainly occurring during meal hours (and especially at nighttime), would be expected from sources that do not contain significant EC and exhibit a similar spectral profile as HOA. This constitutes a strong indication that a part of HOA pertains to cooking emissions (cooking organic aerosol, COA). Cooking has recently been recognized as an important source of organic aerosol in urban atmospheres (e.g., Mohr et al., 2012 and references therein), but could not be extracted in our case by PMF2. This is likely due to the lack of high resolution AMS data, which generally aid the differentiation between HOA and COA. Under the assumption that cooking emissions only affect HOA and that the enhancement of HOA/EC primarily stems from the influence of COA on HOA, HOA/EC can be used to provide a crude estimation for the HOA fraction pertaining to cooking, estimated on average as $\sim 20 \%$ of HOA mass. Note that other factors may also affect the variability of HOA, such as its volatilization and reactivity, leading to its depletion with respect to EC and hence to an overestimation of COA contribution. This was shown in this field study (see Supplement and El Haddad et al., 2011a) to only occur during periods of severe photochemistry with ozone levels approaching $200 \mu \mathrm{g} \mathrm{m}^{-3}$ (30 June and 1 July, Fig. S7).

The SVOOA and LVOOA factors mass spectra closely resemble those previously extracted from AMS datasets in other locations (Table 1). A notable difference between the two factors is the fractional contribution of the $\mathrm{CO}_{2}^{+}$fragment at $m / z 44$ (denoted $f_{44}$ ), which is approximately proportional to the elemental $\mathrm{O}: \mathrm{C}$ ratio (Aiken et al., 2008). $f_{44}=0.06$ for SVOOA vs. $f_{44}=0.19$ for LVOOA (Fig. S5, Supplement), corresponding to $\mathrm{O}: \mathrm{C}$ ratios of 0.33 and 0.84 for SVOOA and LVOOA, respectively. Using these values and a mass balance approach, one can provide a crude estimation for the total OOA $\mathrm{O}: \mathrm{C}$ ratios $\left(\mathrm{O}: \mathrm{C}_{\mathrm{OOA}} \in[0.48\right.$ 0.72]), applying the following linear relationship between the SVOOA fraction in OOA (SVOOA/OOA) and the O : C ratio: $\mathrm{O}: \mathrm{C}=-0.51 \times \mathrm{SVOOA} / \mathrm{OOA}+0.84$. Increased relative oxygenation in LVOOA is expected to correlate with increased particle age (Lanz et al., 2007; Aiken et al., 2008; Ulbrich et al., 2009; Heald et al., 2010; Liggio et al., 2010) and decreased volatility (Jimenez et al., 2009). This hypothesized age difference is consistent with the trends of these two factors, as discussed below.

Unlike the SVOOA factors extracted from previous studies where the factor variability is thought to be primarily driven by its volatility (e.g., Lanz et al., 2007), the SVOOA only shows moderate correlation with particulate nitrate, a semi volatile specie that mainly partitions into the particle phase under low temperature and high relative humidity (typically during nighttime). Instead, SVOOA most significantly correlates with methacrolein + methyl vinyl ketone (MACR+MVK), short-lived early-generation products of isoprene (a major biogenic VOC) and with acetic acid, a 


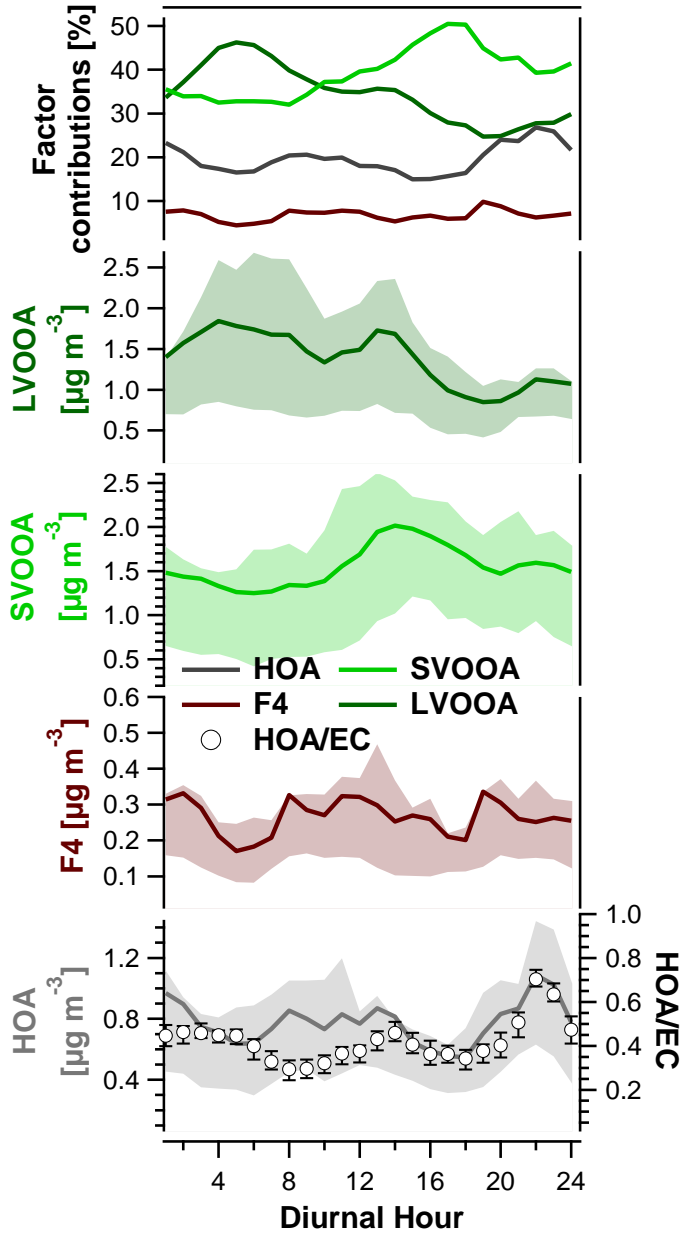

Fig. 4. Diurnal profiles of AMS/PMF2 factors. Solid lines denote average profiles and dashed areas denote P25-P75 ranges. The $\mathrm{HOA} / \mathrm{EC}$ ratio and the factors relative contributions to $\mathrm{OA}$ are also shown in the lower and upper panels, respectively.

longer-lived product of VOC oxidation (Table 1, Fig. 3). On average, SVOOA mass builds steadily during the day, with local maxima extending from 12:00 to 16:00 LT (Fig. 4), despite the development of the boundary layer. A corresponding increase is evident in the photochemical reaction products MACR and MVK, ozone and acetic acid (Fig. S6). This regular and substantial enhancement in SVOOA during peak photochemical periods and its tight correlation with MACR+MVK suggest that SVOOA mainly comprises short-lived locally-formed early-generation oxidation products of VOCs, dominated by biogenic precursors. By contrast, LVOOA appears to be a major constituent of the aged background aerosol, as evidenced by its strong correlation with long-lived species attributed to regional transport, such as acetone and inorganic sulfate (Table 1, Fig. 3 and diurnal profiles in Figs. 4 and S6). Nevertheless, periods with elevated sulfate but no significant LVOOA still occur (Fig. 3), corresponding to air masses transported from the Mediterranean (e.g., 1-3 July) or impacted by direct sulfate emissions from industrial heavy fuel combustion (e.g., 11-12 July). LVOOA mixing ratios constantly rise throughout the night and exhibit a local minimum in late afternoons due to mixing within an increasingly deeper boundary layer (Fig. 4). Such a pattern is further evidence for the regional behavior of LVOOA, as opposed to a fresh SOA locally formed during midday peaks of photochemistry. The temporal trends of SVOOA and LVOOA and the difference in their oxygenation levels provide compelling evidence that their variability is primarily driven by the air masses photochemical age, with SVOOA comprising freshly formed short-lived species and LVOOA consisting of longer-lived aged components. Similar behavior had been previously reported for large biogenic secondary organic aerosol events from eastern Canadian forests (Slowik et al., 2010). The variability in the SVOOA and LVOOA relative contributions with aging is further investigated in Sect. 5. In the literature, the term aging is used to describe numerous processes, including oxidative (reactions with $\mathrm{OH}, \mathrm{O}_{3}$ and $\mathrm{NO}_{3}$ ) or non-oxidative pathways (e.g., glyoxal uptake, oligomer formation) taking place in the gas phase, particle phase or aqueous phase (Hallquist et al., 2009; Lee et al., 2012; Liu et al., 2012 and references therein). The increase in the OOA O:C ratio observed with aging seems to suggest that the OOA evolves via oxidative pathways most probably dominated by gas phase reactions which are considerably faster than heterogeneous processes (DeCarlo et al., 2008). However, we believe that our data do not permit excluding other aging pathways. Therefore the generic term aging will be henceforth used to collectively designate the aforementioned processes.

The fourth factor (F4) revealed by the analysis exhibits a similar spectral profile as HOA, typical of hydrocarbons from primary combustion emissions, dominated by fragments at $\mathrm{m} / z$ 55, 57 and 69 (Fig. S5). It should be noted though that F4 mass spectrum is characterized by higher contributions from fragments at $m / z 41,51,55$ and 67 , which may be related to unsaturated and aromatic hydrocarbons. The distinct time series of $\mathrm{F} 4$, strongly correlating with heavy metals (including $\mathrm{Pb}$ (Fig. 3), Cs, Mo, Fe, La, V, Zn, Ni and Co) and polycyclic aromatic compounds (PAHs, Fig. 3), unambiguously relates this factor to industrial emissions. Similar to industrial OA apportioned by CMB, F4 exhibits low background levels episodically intercepted by remarkable ten-fold increases (Fig. 3). Such wide variability in F4 contributions is due to the fact that industrial emissions constitute a localized point source, whose influence strongly depends on local meteorology (El Haddad et al., 2011a). That is, enhancements in F4 are perceived when the wind shifts most often in late mornings (Figs. 1 and 4) to the west/southwest (225-275 ${ }^{\circ}$, Fig. 5). These periods also coincide with elevated ultrafine particles number and $\mathrm{SO}_{2}$ concentrations (Figs. 5 and S6). This result represents, to the best of our knowledge, the first assessment of the overall contribution of OA from industrial emissions, which, due to the wide variability of processes applied (El 
a) particle number $\left[\mathrm{cm}^{-3}\right] \quad 0$
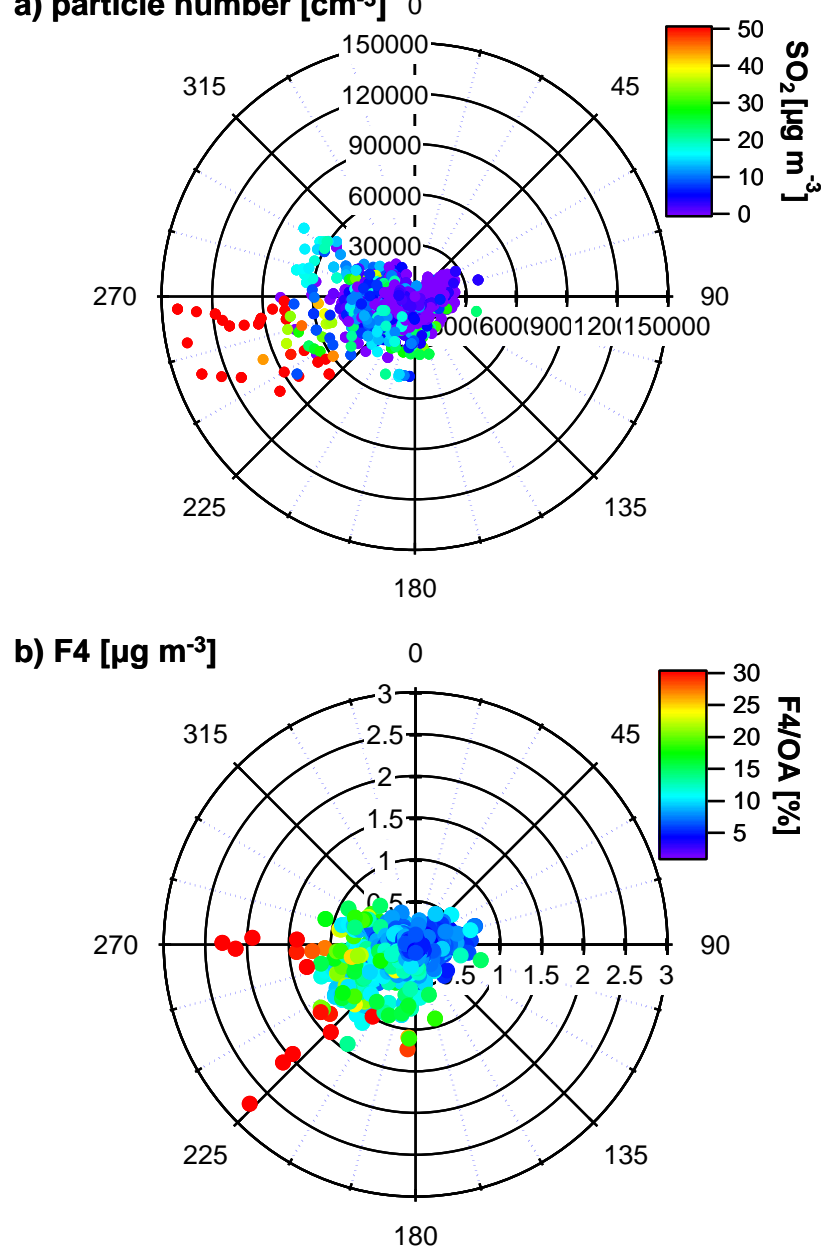

Fig. 5. Polar plots of (a) particle number color coded by $\mathrm{SO}_{2}$ concentrations and (b) concentrations of industrial factor F4 color coded by the contribution of this factor to total OA.

Haddad et al., 2011a) are exceedingly complex to apportion using common approaches (e.g., CMB).

\subsection{Source contributions: AMS/PMF2 vs. CMB}

Figure 6 compares the AMS/PMF2 results discussed above with marker-based CMB results from El Haddad et al. (2011a). These are two independent source apportionment techniques applied to independent measurements, with the former relying on the covariance between the AMS mass fragments and the latter heavily based on the ratios between markers and total carbon mass (marker-to-OC) in source profiles. Limitations, uncertainties and assumptions associated with both techniques include measurement uncertainties (AMS and markers), uncertainties in PMF2 (e.g., number of factors considered) and the source profile selection in CMB (e.g., non-representative or omitted profiles), uncertainties in the $\mathrm{OM} / \mathrm{OC}$ ratios, reactivity of organic markers, adsorption

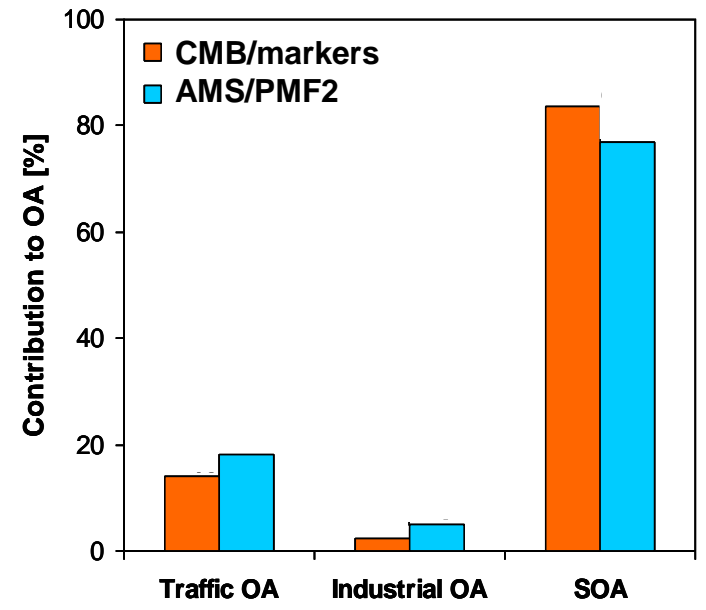

Fig. 6. Comparison between $\mathrm{CMB} /$ markers and AMS/PMF2. For the AMS/PMF2, Traffic OA, industrial OA and SOA denote HOA, F4 and the sum of SVOOA and LVOOA, respectively. For CMB, industrial $\mathrm{OA}$ represents the aggregate contribution from three processes: coke production, metal smelting and shipping/oil burning; SOA is the fraction that is not apportioned to primary sources.

artefacts onto filters and differences in size cut-offs between HiVol samplers $\left(\mathrm{PM}_{2.5}\right)$ and AMS $\left(\mathrm{PM}_{1}\right)$. Nevertheless, both models compare well, providing strong support to our source apportionment results.

For industrial emissions, AMS/PMF2 predicts that during the time frame of the study, F4 contributes on average only $5.1 \%$ of total OA or $\sim 0.22 \mu \mathrm{g} \mathrm{m}^{-3}$, despite significant petrochemical and steel industries in the area. In comparison, CMB estimates lower contributions $(2.3 \%$ of OA), which may be due to omitted profiles for fugitive industrial emissions. Another plausible explanation is that F4 might encompass SOA formed within the industrial emission plumes while in transit to the measurement site, a fraction that is not considered by CMB to pertain to industrial emissions. The high contribution from oxygenated fragments, e.g., $m / z 44\left(\mathrm{CO}_{2}^{+}\right)$, in $\mathrm{F} 4$ mass spectrum (Fig. S5) and the concomitant formation of new particles in industrial plumes (Fig. 5) qualitatively support the latter premise. Traffic emissions (HOA) are estimated by AMS/PMF2 to contribute appreciable amounts of OA essentially every day, accounting on average for $0.72 \mu \mathrm{g} \mathrm{OA} \mathrm{m}{ }^{-3}$ or $18 \%$ of total OA. Slightly lower contributions are estimated by CMB (14\% of the total OA), most likely due to inputs from cooking emissions into HOA (Sect. 3.1) and/or the photochemical decay of vehicular emission markers considered in CMB (e.g., hopanes, El Haddad et al., 2011a). The main finding from this comparison is the overwhelming contribution of SOA predicted by both AMS/PMF2 and CMB, accounting for $\sim 80 \%$ of total OA or $3.1 \mu \mathrm{g} \mathrm{m}^{-3}$ of OOA. Such a result naturally prompts the question of the identity and origins of the main OOA precursors. 


\section{Fossil vs. non-fossil precursors of OOA: predominance of biogenic SOA}

To gain insights into the origins of OOA precursors, the AMS/PMF2 estimates were combined with ${ }^{14} \mathrm{C}$ measurements. This combination is based on mass balance equations, in which each of the AMS/PMF2 factors is considered to comprise a fossil and a non-fossil component (see Supplement: Sect. S9, Eqs. $2-11$ ). We designate by $a_{i}$ (Eq. 8 in Supplement) and $b_{i}$ (Eq. 9 in Supplement) the relative contributions from fossil and non-fossil sources to the AMS/PMF2 factor $i$. Solving these equations involves a multiple regression analysis, which utilizes as input data OC/EC measurements, ${ }^{14} \mathrm{C}$ content in total carbon $(\mathrm{TC}=\mathrm{OC}+\mathrm{EC})$ and AMS/PMF2 estimates. The technique is essentially based on the co-variability between the AMS/PMF2 factors and the fossil and non-fossil OA mass. Conceptually, it assumes constant $a_{i}$ and $b_{i}$ within each of the AMS/PMF2 factors, while these contributions may significantly vary over the course of the experiment. The residual analysis presented in the Supplement (Sect. S9.2.1, Figs. S8 and S9) indicates that overall $a_{i}$ and $b_{i}$ well capture the levels and the variability of the measured fossil and non-fossil carbon concentrations. Therefore, and in the current dearth of clearly better techniques, we believe that $a_{i}$ and $b_{i}$ obtained using a multivariate analysis provides the best estimate of campaign-average contributions of fossil and non-fossil sources to AMS/PMF2 factors. The analysis yields 6 OA components (open circles Fig. 7a), including 2 primary fractions (HOA and F4) and 4 secondary fractions discriminated according to their origins and oxygenation rates (fossil SVOOA $\left(\mathrm{SVOOA}_{\mathrm{F}}\right.$ ), fossil LVOOA $\left(\right.$ LVOOA $\left._{\mathrm{F}}\right)$, non-fossil SVOOA (SVOOA $\left.\mathrm{NF}\right)$ and non-fossil LVOOA ( LVOOA $\left._{\mathrm{NF}}\right)$ ).

To assess the sensitivity of the regression analysis to underlying measurement and modeling uncertainties and biases, the input variables in the mass balance equations were randomly varied within a predetermined uncertainty range (see Sect. S9.2, Supplement), using a random sampling algorithm (pseudo Monte Carlo calculation). We have considered uncertainties in the measurements of EC/OC and ${ }^{14} \mathrm{C}$ and in the AMS/PMF2 analysis (i.e., variability of source contributions with FPEAK and the contamination of HOA by cooking). We have also included biases between online and offline measurements, related to $\mathrm{OM} / \mathrm{OC}$ ratios, filter adsorption artefacts and size cut-off differences between the AMS and the filter sampler. Incorporating the variables generated by the random sampling algorithm into the mass balance equations (solved by the regression analysis), we produced 500 realizations of possible solutions, graphically represented in Fig. 7a as probability density distributions (solid lines). We note that the width of these distributions is essentially a direct consequence of the predetermined uncertainty ranges. These ranges constitute our best estimates of the uncertainties and biases affecting the parameters used in

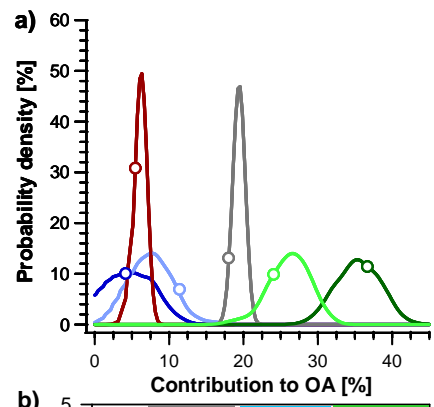

OA fractions
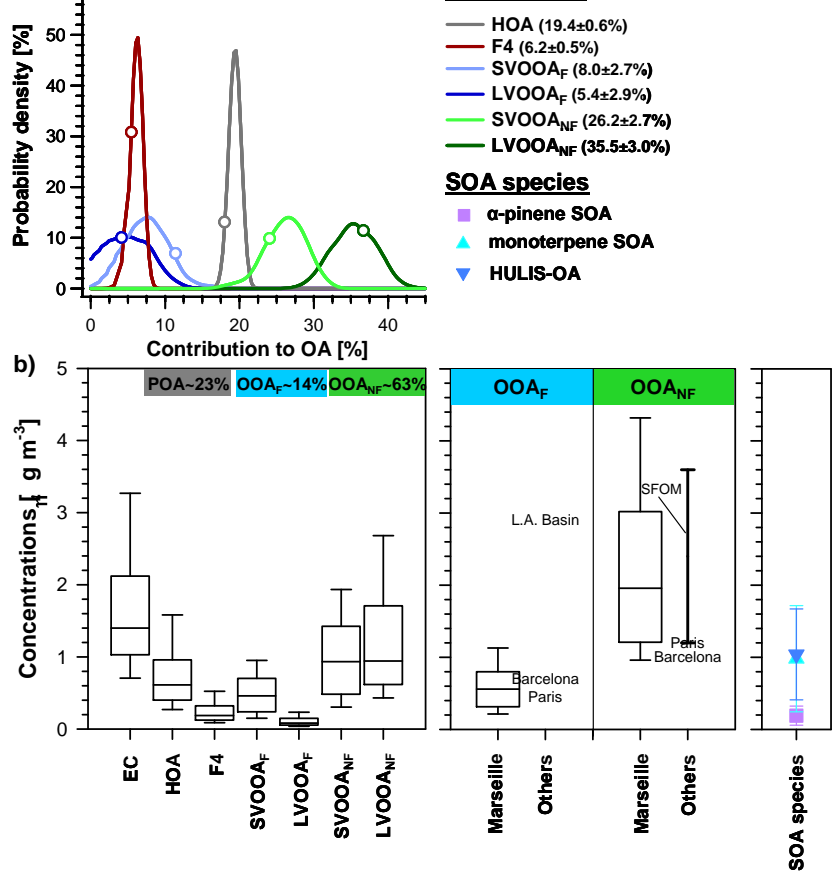

Fig. 7. Fossil and non-fossil origins of POA (HOA and industrial OA, F4) and OOA (SVOOA and LVOOA). (a) The open circles denote estimates determined using a multiple regression approach combining AMS/PMF2 results with ${ }^{14} \mathrm{C}$ measurements. The sensitivity of these estimates to different uncertainties and biases are presented by solid lines as frequency distributions of the contributions of the different fractions, calculated using a random sampling algorithm. From this, it is possible to determine the best estimates for the contributions of OA fractions and their associated uncertainties (see figure legend). Differences between the best estimates determined using the random sampling algorithm (fig. legend) and those determined using the multiple regression approach (open circles) provide an estimation of the potential biases; the estimation shows that we might have underestimated the contributions of F4, HOA, $\mathrm{SVOOA}_{\mathrm{nf}}$ and $\mathrm{LVOOA}_{\mathrm{f}}$ by $9 \%, 6 \%, 5 \%$ and $23 \%$, respectively, and overestimated the $\mathrm{SVOOA}_{\mathrm{f}}$ and $\mathrm{LVOOA}_{\mathrm{nf}}$ by $34 \%$ and $5 \%$, respectively. (b) Contributions, in $\mu \mathrm{g} \mathrm{m}^{-3}$, of OA fractions during the campaign obtained using the multiple regression estimations in (a) (open circles). Fossil and non-fossil OA fractions estimated here are compared with results reported for summertime in other urban sites: Barcelona (Minguillòn et al., 2011), Paris (Crippa et al., 2013), LA Basin (Bahreini et al., 2012) and in forested sites (termed SFOM, for Secondary Forest Organic Matter, Leaitch et al., 2011) for the same range of temperatures recorded during the campaign $\left(18-26^{\circ} \mathrm{C}\right.$, Fig. 1).

the mass balance equations; their determination is justified in the Supplement (Appendix A).

The probability density distributions in Fig. 7a substantially enhance our capability to evaluate the aggregate measurement and model uncertainties and biases related to the different fractions apportioned. Results show that all 6 
fractions are statistically significant with contributions higher than $0(Z$ equal $23,7.4,2.8,1.7,9.2,12$ for $\mathrm{HOA}, \mathrm{F} 4$, $\mathrm{SVOOA}_{\mathrm{f}}, \mathrm{LVOOA}_{\mathrm{f}}, \mathrm{SVOOA}_{\mathrm{nf}}$ and $\mathrm{LVOOA}_{\mathrm{nf}}$ respectively, with $Z=$ average/uncertainty). Purely affected by PMF analysis errors, the uncertainties associated with the contributions of primary components (HOA and F4) are below $10 \%$. Likewise, non-fossil OOAs are well resolved by the model and subjected to low uncertainties of around $10 \%$. Conversely, uncertainties are higher for fossil OOAs $(\sim 36 \%$ and $\sim 58 \%$ for $\mathrm{SVOOA}_{\mathrm{f}}$ and $\mathrm{LVOOA}_{\mathrm{f}}$, respectively), mainly due to uncertainties in measuring $\mathrm{EC}$ and estimating fossil POA contributions (AMS/PMF2 uncertainties and contribution of COA to HOA).

In spite of the wide range of uncertainties related to some of the fractions, results in Fig. 7 clearly highlight our ability to identify the contribution from different OA components. For example, it is clear that LVOOA derives almost entirely from non-fossil precursors $\left(\mathrm{LVOOA}_{\mathrm{nf}} / \mathrm{LVOOA}=89 \pm 7 \%\right.$, average \pm uncertainties), in line with an aged, regional OOA, marginally affected by local anthropogenic sources. By contrast, SVOOA includes a slightly larger fraction of fossil SOA $\left(\mathrm{SVOOA}_{\mathrm{nf}} / \mathrm{SVOOA}=75 \pm 8 \%\right)$, most probably due to local inputs of fresh OOA from anthropogenic precursors (Fig. 7). The most salient element revealed by this analysis is that OOA is overall clearly governed by non-fossil SOA (uncertainty of $\sim 10 \%$ ), accounting for $80 \pm 8 \%$ of the total OOA, despite extensive industrial and urban emissions in the area at large. Confirming our initial suggestions in El Haddad et al. (2011b) that OOA is mainly attributed to biogenic SOA, this result is inextricably linked to the prevalence of regional sources over local anthropogenic emissions during the measurement period.

The modest contribution of fossil OOA found here ( $\sim 14 \%$ of OA or $0.65 \pm 0.14 \mu \mathrm{g} \mathrm{m}^{-3}$, Fig. $\left.7 \mathrm{~b}\right)$ and at other European sites (e.g., Barcelona and Paris, Fig. 7b) contrasts sharply with results reported for the LA Basin (Bahreini et al., 2012). There, the average levels of fossil OOA are 4-5 times higher ( $\sim 35 \%$ of OA or $2.9 \mu \mathrm{g} \mathrm{m}^{-3}$, Fig. $\left.7 \mathrm{~b}\right)$, despite lower fossil EC concentrations ( $\mathrm{EC}_{\text {Marseille }} \sim 1.8 \mu \mathrm{g} \mathrm{m}^{-3}$ vs. $\mathrm{EC}_{\mathrm{LA}}<1 \mu \mathrm{g} \mathrm{m}^{-3}$ ). Combined with the higher proportions of gasoline cars in the U.S. compared to Europe, this feature would support the hypothesis proposed by the authors that gasoline emissions dominate over diesel in the formation of fossil SOA (Bahreini et al., 2012). By contrast, the prevalence of diesel cars in the European fleet would explain the higher EC levels measured in our case.

For the total non-fossil OOA, average levels estimated in our case ( $\sim 63 \%$ of OA, $2.4 \pm 0.15 \mu \mathrm{g} \mathrm{m}^{-3}$, Fig. $\left.7 \mathrm{~b}\right)$ closely match levels at temperate forests in Canada (Leaitch et al., 2011), recorded for an equivalent temperature range (18$26^{\circ} \mathrm{C}$ ). This implies that biogenic emission strength and SOA formation potential appear comparable for the two locations, despite potentially strong differences in tree-cover and aging conditions (e.g., higher $\mathrm{NO}_{\mathrm{X}}$ in our case). By contrast, levels at the FORMES site in Marseille far exceed those estimated for Paris and Barcelona $\left(\sim 1 \mu \mathrm{g} \mathrm{m}^{-3}\right)$, presumably because of differences in the biogenic emissions strength and the influence of meteorology (e.g., clean air masses from the Atlantic in Paris).

To assess the relative importance of individual biogenic precursors in the formation of non-fossil OOA, we compare the non-fossil OOA concentrations estimated above with SOA mass derived from these precursors (Eq. 2), based on the levels of their oxidation products measured in El Haddad et al. (2011b). Amongst biogenic VOCs, monoterpenes are widely accepted OOA precursors (e.g., Hallquist et al., 2009; Slowik et al., 2010 and references therein). We estimate an $\alpha$-pinene SOA concentration of $0.18 \mu \mathrm{g} \mathrm{m}^{-3}$, or $7.1 \%$ of total non-fossil OOA, using the oxidation products in Fig. 2. This relative contribution $(7.1 \%)$ should be viewed as an upper limit, as the calculation assumes that $\alpha$-pinene oxidation products occur in $\mathrm{PM}_{1}$ and are not affected by adsorption artefacts onto filter sample. Note that $\alpha$-pinene accounts on average for only $\sim 18 \%$ of the total monoterpene emissions from Mediterranean vegetation (e.g., Lang-Yona et al., 2010), but the lack of information about the oxidation products from other monoterpenes prevents a direct estimation of their contribution to biogenic OOA. Nevertheless, given that the remaining monoterpenes have approximately comparable SOA yields $(Y)$ as $\alpha$-pinene (Ng et al., 2006), the aggregate contribution of monoterpene SOA can be indirectly estimated as $\sim 0.95 \mu \mathrm{g} \mathrm{m}^{-3}$ or $42 \pm 20 \%$ of the total non-fossil OOA ( $20 \%$ denotes the variability of monoterpene SOA contributions during the experiment; see Fig. 7).

Whilst monoterpenes account on average between 40 and $60 \%$ of the total biogenic VOCs in the region (Parra et al., 2004, Steinbrecher et al., 2009), the remainder is mostly isoprene, which, given its much lower SOA yield $\left(Y_{\text {isoprene }} \sim 1\right.$ $4 \%$ vs. $Y_{\text {terpenes }}>15 \%$; $\mathrm{Ng}$ et al., 2006; Kroll et al., 2006), cannot explain the high non-fossil OOA concentrations. In this regard, based on the levels of isoprene oxidation products in our conditions, we had previously estimated an isoprene SOA concentration of $\sim 0.05 \mu \mathrm{g} \mathrm{m}^{-3}$, i.e., only $\sim 2 \%$ of total non-fossil OOA (El Haddad et al., 2011b). By contrast, sesquiterpenes are effective SOA precursors $(Y \sim 0.7$, $\mathrm{Ng}$ et al., 2006), but the magnitude of their emissions is widely variable across species and at different environmental and phenological states, such that their contribution to biogenic VOCs burden remains an open question (Duhl et al., 2008). Based on biogenic emission inventories for $\mathrm{Eu}-$ rope, sesquiterpenes are estimated to contribute to only 1$2 \%$ of the overall amount of biogenic compounds (Steinbrecher et al., 2009 and references therein). We have previously reported a $\beta$-caryophyllene SOA contribution of only $0.015 \mu \mathrm{g} \mathrm{m}^{-3}$ ( $0.6 \%$ of total non-fossil OOA, El Haddad et al., 2011b). Considering that the remaining sesquiterpenes have SOA yields comparable to those of $\beta$-caryophyllene ( $\mathrm{Ng}$ et al., 2006) and that the latter accounts on average for $\sim 19 \%$ of the total sesquiterpene emissions (15-25\% depending on the considered inventory; Sakulyanontvittaya 
et al., 2008 and references therein), the aggregate contribution of sesquiterpene SOA can be indirectly estimated as $\sim 0.08 \mu \mathrm{g} \mathrm{m}^{-3}$ or only $\sim 3.5 \%$ of the total non-fossil OOA.

The contribution of other biogenic (e.g., oxygenated VOCs) or urban non-fossil (e.g., land use) precursors in the formation of non-fossil OOA cannot be excluded. However, we do not believe that the above estimates are accurate to more than a factor of two given the large uncertainties and the crude assumptions in their calculations. These include uncertainties related to SOA yields, varying biogenic VOC profiles with location and the marker-based approach (Eq. 2). In particular, the latter intrinsically assumes a stable ratio between the marker compounds and SOA mass (Eq. 2) regardless of the prevailing atmospheric conditions (e.g., low vs. high $\mathrm{NO}_{\mathrm{X}}$ ) and the aerosol photochemical age (the stability of the marker/SOA ratios with aging is examined in Sect. 6). Therefore, the main conclusion from this analysis is the very high contribution of monoterpenes in the formation of nonfossil OOA, in agreement with previous results reported for other biogenically-influenced locations that suggest $22-50 \%$ of total OOA may arise from monoterpenes oxidation (Sjostedt et al., 2011).

\section{Dynamics of OOA with aging}

While both SVOOA and LVOOA appear to predominantly originate from biogenic precursors, the wide variability observed in their relative strength (Sect. 3.1) seems to be primarily governed by differences in their photochemical age, with LVOOA prevailing in highly aged air masses. If LVOOA arises from further processing of biogenically influenced short-lived early-generation products in SVOOA, highly processed OOA is then expected to be more oxygenated with higher (lower) LVOOA/OOA (SVOOA/OOA) and $\mathrm{O}: \mathrm{C}$ ratios. Fig. 8 considers this hypothesis, investigating the variability of OOA relative composition and oxygenation levels as a function of the toluene/benzene ratio $(T / B)$, changes in which are taken as indication of photochemical aging. Toluene and benzene are concurrently emitted by traffic (Fig. S6, Supplement), but due to toluene's higher reactivity towards $\mathrm{OH}$, it is depleted against benzene, resulting in lower $T / B$ ratios in aged air masses (the effect of other oxidants (i.e., $\mathrm{O}_{3}$ and $\mathrm{NO}_{3}$ ) on our analysis is discussed below). This methodology has been successfully utilized on numerous occasions (e.g., de Gouw et al., 2005; Liggio et al., 2010).

We recognize that using the $T / B$ ratio to infer the age of a non-fossil dominated OOA inherently assumes that biogenic and anthropogenic emissions originate from the same locations upwind of the observation site and undergo similar extent of oxidation during transport. Indeed, the presence of significant inputs from fresh anthropogenic emissions into an existing regional OOA would revert the $T / B$ ratio to higher values, erroneously reflecting unprocessed aerosols. While clearly a major assumption, we presume that such anthropogenic inputs would only occur significantly during rush hours. Anthropogenic compounds would then instantly mix with the regional background where they concomitantly react along with biogenic precursors throughout the day.

The above assumption is verified in Fig. 8, where, apart from episodes of local pollution, aged air masses with low $\operatorname{Ln}(T / B)$ coincide with a more oxygenated OOA characterized by lower SVOOA/OOA ratios. Two patterns can be distinguished:

- First, an increase in the photochemical age can be observed over the course of the experiment (Fig. 8a), consistent with an increasingly oxygenated OOA (increase of $\mathrm{O}: \mathrm{C}$ ratios from $\sim 0.45$ to $\sim 0.65$ ). While the reason for this increase remains unclear, the fact that both the particle and the gas phase measurements exhibited signs of increased air mass aging indicates that this cannot be ascribed to changes in the anthropogenic toluene and benzene emissions, but rather represents a real increase in the $\mathrm{OH}$ concentrations or in the air masses transport time.

- Second, the air masses photochemical age and OOA oxygenation levels exhibit consistent diurnal profiles (Fig. 8b), with decreasing $\operatorname{Ln}(T / B)$ and increasing contributions of aged OOA during nighttime. Note that greater scattering is observed in the $\operatorname{Ln}(T / B)$ diurnals (on average variability of $\sim 48 \%$, Fig. 8 b), likely due to intermittent inputs of benzene and toluene from fresh traffic or industrial emissions (frequently between 08:00-11:00 and 18:00-21:00 LT, Fig. 8b). The nighttime increase of air mass age coincides with a shift in the wind direction to the east/northeast (Fig. 1, Fig. 8) and can be interpreted as stemming from the specific local meteorology in the region. It appears that during daytime, the increase of urban and biogenic fresh emissions, together with an active photochemistry, engender the formation of a fresh moderately oxygenated OOA dominated by SVOOA (O: C $\sim 0.5$, Fig. $8 \mathrm{~b})$. This aerosol further ages while transported away from Marseille by the sea breeze $\left(225-270^{\circ}\right)$. During the night, the land breeze $\left(45-90^{\circ}\right)$ brings the further processed air masses (low $T / B$ ratios) back to Marseille, injecting into an increasingly shallow boundary layer a highly oxygenated OOA, dominated by LVOOA $(\mathrm{O}: \mathrm{C} \sim 0.65$, Fig. $8 b)$.

The close relationship between OOA oxygenation levels and $\operatorname{Ln}(T / B)$ observed in Fig. 8 implies, on the one hand, that anthropogenic and biogenic emissions rather arise from spatially diffused sources and undergo similar extent of aging before arriving to the measurement site. This is consistent with the environs close to Marseille, composed of residential areas and sparse woodlands interspersed amongst roads and highways, plus the fact that both anthropogenic and biogenic 

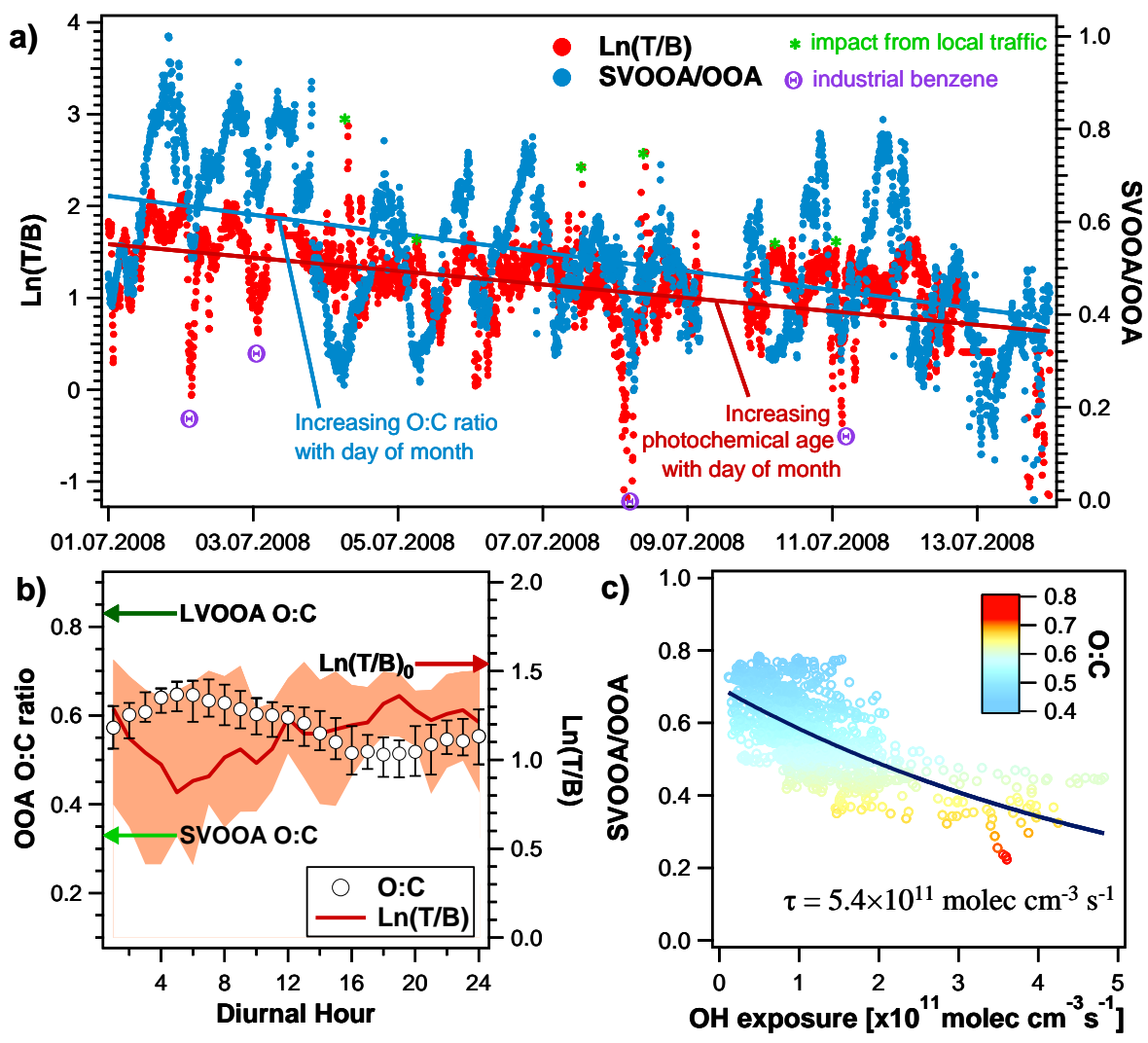

Fig. 8. OOA photochemical aging. (a) presents the correlation between $\operatorname{Ln}(T / B)$ and SVOOA/OOA, indicating the photochemical transformation of SVOOA into LVOOA in aged air masses with low $\operatorname{Ln}(T / B)$. Episodes of local pollution affecting the toluene/benzene ratios are indicated by green stars for traffic related episodes (high toluene/benzene ratios) and by purple hexagons for industrial emissions of benzene. The brown and blue lines represent the fits vs. time of $\operatorname{Ln}(T / B)$ and SVOOA/OOA, respectively, indicating an increase of air masses photochemical age with day of month. (b) represents the diurnal patterns for $\operatorname{Ln}(T / B)$ and OOA O : C (which is inversely proportional to the SVOOA/OOA ratio). It shows that the photochemical age of air masses increases during nighttime, leading to higher $\mathrm{O}: \mathrm{C}$ ratios. Using toluene / benzene ratios, we estimated the $\mathrm{OH}$ exposure in molecules $\mathrm{cm}^{-3} \mathrm{~s}^{-1}$ (Eq. 3). In (c), SVOOA/OOA is plotted against the OH ex-

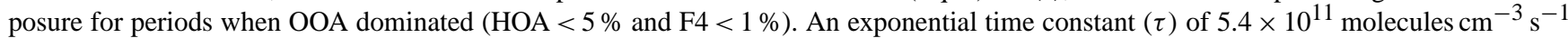
is estimated by fitting the data with an exponential decay function.

emissions exhibit similar behavior with enhanced emissions during daytime that ages while transported by land and sea breezes. On the other hand, combined with the predominance of non-fossil OOA sources, results in Fig. 8 suggest that the variability in the OOAs relative contributions does not mainly stem from differences in their parent VOC precursors, but rather from differences in their photochemical age, showing that LVOOA appear to emerge from additional oxidation of early-generation semi-volatile SOA species.

Based on the relationship observed in Fig. 8, changes in $T / B$ ratio can be used as a first approximation to infer the OOA photochemical age, as parameterized in Eq. (3) by the $\mathrm{OH}$ exposure:

$\mathrm{OH}$ exposure $=$

$\left(\ln \left(\frac{T}{B}\right)_{0}-\ln \left(\frac{T}{B}\right)_{t}\right) /\left(K_{\mathrm{OH}, T}-K_{\mathrm{OH}, B}\right)$.
Here, $(T / B)_{0}$ denotes the average toluene/benzene ratio at emission, estimated as equal to 4.5 based on the current measurements (Fig. 8b) and emission profiles (e.g., Schauer et al., 1999). $(T / B)_{t}$ is the ratio measured at a time $t . K_{\mathrm{OH}, T}$ and $K_{\mathrm{OH}, B}$ are respectively the decay rates of toluene and benzene against $\mathrm{OH}$ (Atkinson and Arey, 2000). The effect of localized inputs of benzene and toluene into the background air is minimized by (1) considering only periods when OOA dominated, i.e., HOA and $\mathrm{F} 4$ contributions $<5 \%$ and $1 \%$ of $\mathrm{OA}$, respectively, and (2) and excluding spikes in the $(T / B)_{t}$ ratio indicating contributions from local industries. This filtering process excluded $\sim 37 \%$ of the data. For the remaining data, the contribution of SVOOA to OOA is plotted in Fig. 8c against the resulting $\mathrm{OH}$ exposures and fitted by an exponential decay function, from which a time constant, $\tau$, of $5.4 \times 10^{11}$ molecules $\mathrm{cm}^{-3} \mathrm{~s}^{-1}$ is inferred. When considering this value an essential distinction should be drawn between an estimation of the absolute decay rate of SVOOA 
or the formation rate of LVOOA and that of the OH exposures or timescales needed to achieve the relative changes observed within the OOA composition. Here, $\tau$ is representative of the latter, indicating the rate of the net oxygen gain in OOA caused by oxidative aging. For example, $\tau$ does not reflect whether this oxygen gain is associated with an increase in carbon mass due to the formation of additional functionalized LVOOA components or with a carbon mass loss with the fragmentation of SVOOA into more volatile compounds (e.g., $\mathrm{CO}, \mathrm{CO}_{2} \ldots$, Kroll et al., 2009). The use of an exponential decay to fit our data is based on the underlying assumption that OOA oxygenation levels are expected to attain a steady state, resulting from a balance between functionalization and fragmentation pathways, where OOA is composed of LVOOA with highly oxygenated components less prone to additional processing. Another important consideration is that the analysis neglects SOA formation by reactions with $\mathrm{O}_{3}$ and $\mathrm{NO}_{3}$. It should be noted though that, while these oxidants can play an important role in the oxidation of double bonds and hence are essential during the initial oxidation steps that forms SVOOA, the later steps leading to the transformation of SVOOA into LVOOA are expected to predominantly proceed via $\mathrm{OH}$ chemistry.

Furthermore, while we believe that isolating the periods when OOA dominated clearly diminishes the effect of the recurring local inputs of benzene and toluene, the $\tau$ value determined here should still be regarded as a lower limit. For example, significant inputs of benzene and toluene from emission to the time of sampling yields apparent $\mathrm{OH}$ exposures lower than the actual ones to which the OOA was subjected to and hence to higher $\tau$. It should be also mentioned that $\tau$ is not influenced by errors in the $(T / B)_{0}$ estimation (Eq. 3), which only affect the $\mathrm{OH}$ exposures absolute values (Fig. 8).

From Fig. 8c, we estimated that it requires an $\mathrm{OH}$ exposure of $3.2 \times 10^{11}$ molecules $\mathrm{cm}^{-3} \mathrm{~s}^{-1}$ to increase the OOA $\mathrm{O}: \mathrm{C}$ ratio from 0.5 to 0.65 (decrease in SVOOA/OOA from 0.67 to 0.37 ). Assuming typical summertime $\mathrm{OH}$ concentrations in the region $\left(\mathrm{OH}_{06} \mathrm{~h}-20 \mathrm{~h}=5 \times 10^{6}\right.$ molecules $\mathrm{cm}^{-3}$, Liakakou et al., 2009), this value would correspond to $\sim 17 \mathrm{~h}$ of aging under daytime conditions, qualitatively consistent with the variability in the $\mathrm{O}: \mathrm{C}$ ratios observed in Fig. 8b occurring within a short space of time of about $0.5-1 \mathrm{~d}$. This high rate of oxygen gain agrees with previous observations from urban polluted sites (e.g., Mexico City, DeCarlo et al., 2008) and rural sites (e.g., Ontario, Liggio et al., 2010) and with smog chamber and flow tube studies of $\alpha$-pinene aging, reporting $\tau$ values of $2-7 \times 10^{11}$ molecules $\mathrm{cm}^{-3} \mathrm{~s}^{-1}$ for an equivalent $\mathrm{O}: \mathrm{C}$ increase (Chen et al., 2013; Pfaffenberger et al., 2013). Taken together, these results underscore the rapid and pervasive LVOOA production in the atmosphere via the oxidation of semi-volatile SOA species (SVOOA) from different precursors.

\section{Insights into OOA chemical composition: effect of aging}

The observed age and chemical lifetime differences between SVOOA and LVOOA can be used to infer the relative age of SOA species through their correlation with these OOA fractions. That is, the contribution of more aged, longer-lived chemical components is expected to increase in aged aerosol, with higher proportions of LVOOA and higher $\mathrm{O}: \mathrm{C}$ ratios. Figure 9 examines the link between OOA fractions and $\alpha$ pinene SOA, taken as a surrogate for monoterpenes SOA and non-fossil OOA, in general. Discarding periods when the site was directly downwind of the industrial area, defined by the high contributions from anthropogenic precursors, $\alpha$-pinene SOA exhibits a good correlation with SVOOA $(R=0.74$, Table 1). Such behavior is in line with the correlation between SVOOA and isoprene gas-phase oxidation products (Fig. 3) and the high proportions of biogenic OOA (Fig. 7), and supports other ambient measurements suggesting the importance of monoterpenes in forming SVOOA (Slowik et al., 2010; Sjostedt et al., 2011). However, significantly lower correlation is observed between $\alpha$-pinene SOA and LVOOA ( $R=0.47$, Table 1$)$, in spite of the overwhelming contribution from non-fossil precursors to this fraction (Fig. 7). Taken together, these observations seem to suggest a rapid production and a rather short lifetime of the compounds used for estimating $\alpha$-pinene SOA, overall generated and decayed over similar timescales as SVOOA (hours).

The formation of LVOOA via the oxidative aging of SVOOA, likely including $\alpha$-pinene SOA, appears to produce compounds with a different chemical nature. In this respect, the comparison between the contributions of LVOOA and HULIS is revealing (Fig. 9), showing an increase of HULIS fraction in OC from 7 to $18 \%$ when the LVOOA contribution to OA increased from $20 \%$ to $60 \%$. This result suggests that the aging processes involved in the production of LVOOA and the increase of OOA oxygenation level play a key role in the formation of HULIS, which, similarly to LVOOA, can be identified as a long-lived highly oxygenated component formed over longer timescales than SVOOA (0.5-1 day). While this correlation is evidence that a great part of LVOOA may comprise poly-carboxylic compounds, it should be noted that the contributions of LVOOA to OA exceeds by more than threefold the contributions of HULIS to OC. Other potential candidates believed to contribute to LVOOA may include dicarboxylic acids characterized by high $\mathrm{O}: \mathrm{C}$ ratios, together with alcohols and their sulfate esters (organosulfates), all previously identified in our conditions as main contributors to SOA (El Haddad et al., 2011b, 2013).

The compounds used to estimate $\alpha$-pinene SOA span a wide range of $\mathrm{O}: \mathrm{C}$ ratios $(\mathrm{O}: \mathrm{C}=0.3-1$, Fig. 2$)$ and include both early- and later-generation products of $\alpha$-pinene oxidation (Jaoui et al., 2005; Szmigielski et al., 2007). Figure S10 in the Supplement illustrates the distribution of these 
Table 2. Correlation table of $\alpha$-pinene oxidation products revealing three sets of compounds with similar trends: Set 1 includes PNA, PA, and A2, products formed at the early stages of the reaction. Set 2 includes A4, A5 and A6, products that appear at later stages of the reaction and that show a relative increase with OA's oxidation state (Fig. 10). Set 3 includes A1, A3 and A7, products that appear at later stages of the reaction but do not show any increase with OA's oxidation state (Fig. 10).

\begin{tabular}{lrrrrrrrrr}
\hline$R^{2}$ & PNA & PA & A1 & A2 & A3 & A4 & A5 & A6 & A7 \\
\hline PNA & 1.00 & 0.61 & 0.39 & 0.23 & 0.61 & 0.29 & 0.39 & 0.27 & 0.45 \\
PA & & 1.00 & 0.61 & 0.35 & 0.44 & 0.68 & 0.60 & 0.60 & 0.48 \\
A1 & & & 1.00 & 0.36 & 0.72 & 0.72 & 0.74 & 0.77 & 0.86 \\
A2 & & & & 1.00 & 0.37 & 0.48 & 0.57 & 0.43 & 0.32 \\
A3 & & & & & 1.00 & 0.46 & 0.53 & 0.41 & 0.78 \\
A4 & & & & & & 1.00 & 0.92 & 0.95 & 0.65 \\
A5 & & & & & & & 1.00 & 0.93 & 0.69 \\
A6 & & & & & & & & 1.00 & 0.68 \\
A7 & & & & & & & & & 1.00 \\
\hline
\end{tabular}

products in the two-dimensional volatility basis set space (see also Donahue et al., 2012 and reference therein), representing the OOA components in terms of their volatility and oxidation state. Multiple oxidation steps during atmospheric aging are expected to have a strong impact on the distribution of individual $\alpha$-pinene oxidation products. The current hypothesis is that highly aged OOA is likely to be characterized by higher (lower) proportions of later- (early)generation products of $\alpha$-pinene oxidation. This is shown in Fig. 10 by the severe depletion of pinonic acid (PNA) contributions in highly aged OA. The contribution of this earlygeneration product $(\mathrm{O}: \mathrm{C}$ ratio of 0.3$)$ to the total $\alpha$-pinene SOA decreased from $\sim 12$ to $\sim 4 \%$ when the OOA O:C increased from $\sim 0.5$ to $\sim 0.75$. The decay of PNA appears to be concomitant with the formation of the 3 multifunctional later-generation products, A4, A5 and A6 $(\mathrm{O}: \mathrm{C}=0.45$ $0.70)$. These compounds exhibited very similar variability during the measurement period $\left(R^{2}>0.9, n=26\right.$; Table 2$)$; their contributions to $\alpha$-pinene SOA experienced a 3- to 10fold increase for a similar OOA O: $\mathrm{C}$ increase (from $\sim 0.5$ to $\sim 0.75 \%$, Fig. 10). These trends highlight the reactive and dynamic nature of $\alpha$-pinene SOA components, showing a considerable shift from early-generation products, like PNA, in SVOOA to more oxidized compounds in LVOOA.

The study of the correlations (Table 2) between individual $\alpha$-pinene oxidation products reveals another important set of multifunctional later-generation products, including A1, A3 and A7 (Fig. 2). These compounds show moderate correlations $\left(0.41<R^{2}<0.78, n=26\right.$; Table 2$)$ with the less oxygenated compounds of the previous set (A4, A5 and A6), and despite their very high $\mathrm{O}: \mathrm{C}$ ratios $(\mathrm{O}: \mathrm{C}>0.7$, Fig. 2$)$ they do not show any trend with aging (Fig. 10). The exact reason for such behavior is yet to be determined. However, as the variability of OOA components is in our case primarily driven by its photochemical age, one can argue that this lack of correlation between these compounds and LVOOA

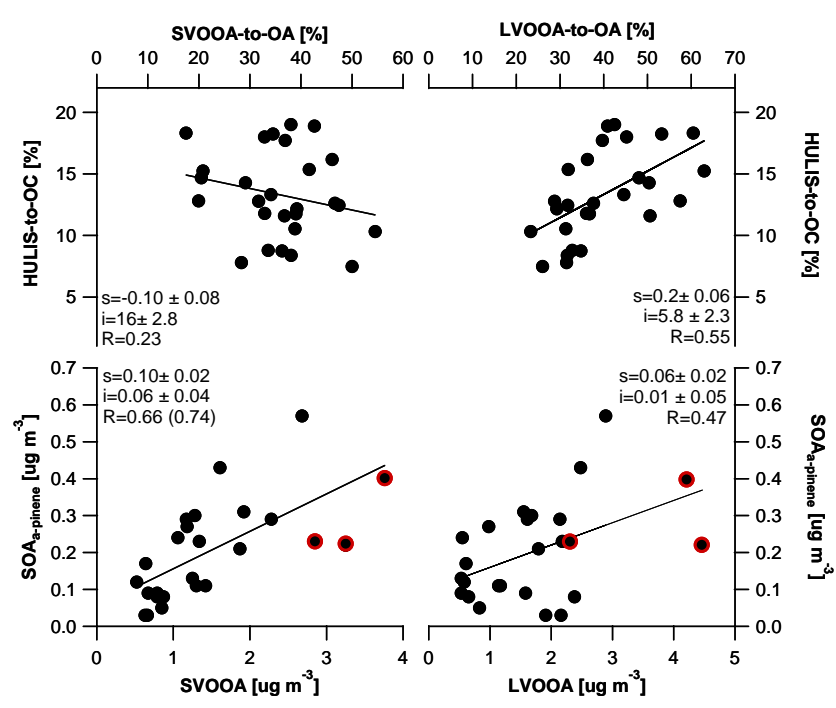

Fig. 9. Correlation between OOA fractions (SVOOA and LVOOA) and SOA components, including HULIS and $\alpha$-pinene SOA estimated following the approach proposed in Kleindienst et al. (2007). For $\alpha$-pinene SOA, absolute concentrations [in $\mu \mathrm{g} \mathrm{m}^{-3}$ ] are compared. Except for periods when the site was downwind of the industrial area (dark read contours) and OOAs had high contributions from anthropogenic precursors, $\alpha$-pinene SOA showed high correlation $(R=0.66$ ) with the SVOOA fraction (excluding data points where the site was downwind of industrial emissions would result in a $R$ value of 0.74 ). For HULIS, the relative contributions [in \%] are compared, because the absolute concentrations of HULIS correlated with both SVOOA and LVOOA. The good correlation between HULIS and LVOOA suggests that a large fraction of LVOOA comprises poly-carboxylic species that are not well represented by the markers of $\alpha$-pinene SOA.

is most likely due to differences in their atmospheric lifetime or in the timescales over which they are formed. For example, laboratory studies show that A7 formation via the $\mathrm{OH}$-initiated oxidation of PNA appears to be faster than the relative increase in LVOOA measured in the field $(\mathrm{OH}$ exposures $\sim 10^{11}$ molecules $\mathrm{cm}^{-3} \mathrm{~s}^{-1}$, Müller et al., 2012). On the other hand, similar to PNA, later-generation products, including A1, A3 and A7, can also photochemically decay, especially via fragmentation pathways, such that their concentrations would not be enhanced in aged OOA (Kroll et al., 2009; Baduel et al., 2011; Chacon-Madrid and Donahue, 2011).

Overall, the correlation analysis in Table 2 and Fig. 10 highlights the wide variability in the relative distributions of $\alpha$-pinene oxidation products within OOA. This transgresses the assumptions underlying the marker-based approach (Eq. 2) and potentially leads to sizeable uncertainties in the $\alpha$-pinene SOA determination. The fact that the variability of $\alpha$-pinene SOA mass overall follows that of SVOOA suggests that under our conditions we may be underestimating the contribution of $\alpha$-pinene and monoterpenes in general 

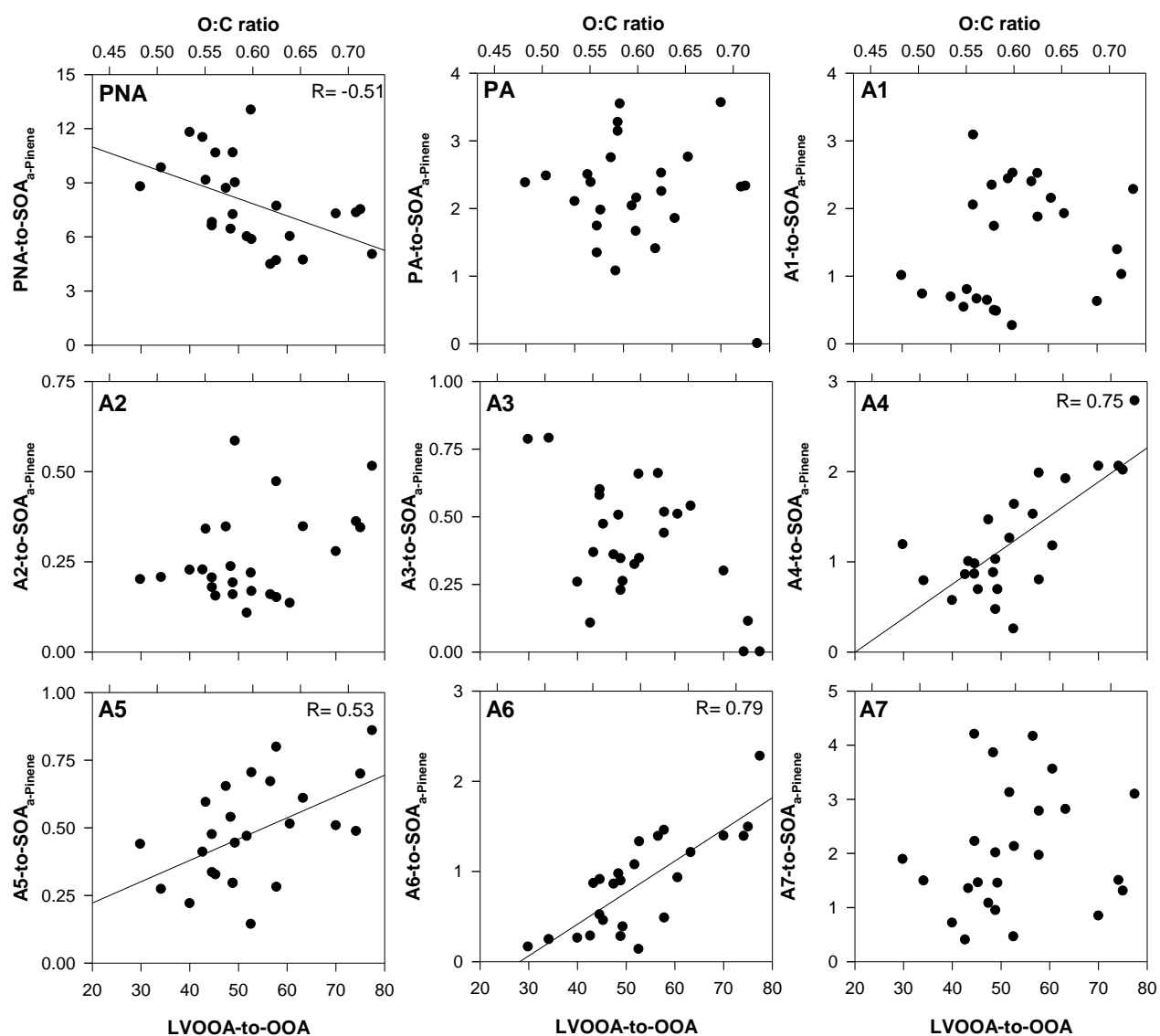

Fig. 10. Correlations between LV-OOA-to-OOA contribution [\%] and the contribution of each of the $\alpha$-pinene oxidation products to the total $\alpha$-pinene SOA [\%]. Also shown are the O : C ratios, calculated using the approach proposed in Aiken et al. (2008).

in the formation of non-fossil OOA (Sect. 4), especially in aged air masses. Including further later-generation products with longer lifetimes in the estimation of $\alpha$-pinene SOA concentrations may allow better capturing of its variability and levels, potentially bridging the gap between non-fossil OOA mass and the contributing precursors (Sect. 4, Fig. 7).

\section{Conclusions}

The aerosol chemical composition was characterized by AMS during the summertime at an urban industrialized site in Marseille (France) and the sources and aging of OA were examined. The dataset was analyzed by PMF2 and the results were compared with previous apportionments obtained using a CMB approach coupled to organic markers and metals. Such systematic comparison is rarely performed in the literature and showed in this work a very good agreement between the two independent approaches, despite the large uncertainties and crude assumptions underlying both techniques. The results presented here constitute the first demonstration of the separation of industrial OA by AMS/PMF2. This emission source contributes only $5 \%$ of OA compared with about
$15 \%$ from vehicular emissions, despite the apparent extensive industrial emissions in the region. Currently, apportioning such emissions using $\mathrm{CMB}$ is hindered by the great number of industrial processes with widely varying profiles. AMS/PMF2 can therefore constitute an alternative approach to apportion such emissions in industrial areas. Our results also illustrate that OOA represents the major fraction, contributing $\sim 80 \%$ of OA mass. Accordingly, we proposed a novel approach, combining AMS/PMF2 data with ${ }^{14} \mathrm{C}$ measurements, to identify and quantify the fossil and non-fossil precursors of this fraction. The proposed approach offers a direct uncertainty analysis, showing that the main conclusions from this study are robust. We demonstrated with high statistical confidence (errors of $10 \%$ ) that, despite extensive urban and industrial emissions, OOA is overwhelmingly nonfossil, with estimated levels of $2.4 \mu \mathrm{g} \mathrm{m}^{-3}$ ( $\sim 80 \pm 8 \%$ of OOA). We assessed the contribution of different biogenic SOA precursors from the levels of their oxidation products (top-down estimation) and showed that under our conditions monotepenes may play a major role in the formation of nonfossil OOA ( $\sim 40 \%$ of non-fossil OOA). In comparison, isoprene SOA was estimated to contribute only $\sim 2 \%$ of nonfossil OOA or $\sim 20$ times less than monotepene SOA. This 
is consistent with bottom-up calculations, based on biogenic emission inventories (for Europe and Mediterranean areas) and smog chamber studies, showing that while monoterpenes are emitted at similar amounts as isoprene, they have up to 20 times higher SOA yields than isoprene.

Using AMS measurements, we were able to elucidate the main processes driving the variability observed in the OOA levels and chemical composition. We showed that while OOA primarily originates from biogenic precursors, its chemical composition markedly varies with aging, evolving from a freshly formed moderately, oxygenated SVOOA into a highly oxygenated aged LVOOA. Our results also reveal the role of these aging processes in the formation of the polycarboxylic compounds in HULIS. These compounds thus appear as long-lived major constituents of LVOOA produced over timescales of several hours in our conditions $\left(10-20 \mathrm{~h}\right.$ at $[\mathrm{OH}]=5 \times 10^{6}$ molecules $\left.\mathrm{cm}^{-3}\right)$. We additionally showed that aging leads to the decay of $\alpha$-pinene earlygeneration products and the formation of later-generation products. Our results suggest that $\alpha$-pinene SOA products characterized here overall represent the fresh components in SVOOA and have rather short lifetimes. Consequently, monoterpenes SOA contributions estimated using these compounds might be underestimated, especially in aged air masses where LVOOA dominates.

Our results highlight that combining AMS measurements with different techniques offers additional and valuable insights into the OOA chemical composition and the influence of aging therein. Further AMS and biogenic SOA component measurements are needed to confirm the trends observed here and to provide better assessment of the formation rate of OOA components and their aging in ambient atmospheres. In particular, it would be worthwhile for future studies to identify with suitable analytical techniques additional later-generation products to better represent aged aerosols, e.g., APi-TOF (Ehn et al., 2012) or CIMS (Eddingsaas et al., 2012a, b). Such combined measurements would enhance our understanding of the aging mechanisms involved in the conversion of SVOOA to LVOOA, and the parameterization of these mechanisms would improve the ability of chemical transport models to sufficiently simulate the global OA burden.

\section{Supplementary material related to this article is available online at: http://www.atmos-chem-phys.net/13/ 7875/2013/acp-13-7875-2013-supplement.pdf.}

Acknowledgements. This work was funded by the "Ministere de l'Ecologie, du Developpement et de l'Amenagement Durable" and by "l'Agence gouvernementale De l'Environnement et de la Maîtrise de l'Energie (ADEME)" under the PRIMEQUAL2 grant no. 0001135 (FORMES program). Accelerator mass spectrometry measurement of ${ }^{14} \mathrm{C}$ was provided by UMS-ARTEMIS (Saclay, France), with a grant from the ARTEMIS program (INSU-CNRS). We also acknowledge the gas phase and aerosol chemistry group
(PSI) for the interactive discussions, and Stephen M. Platt and Helen Langley Dewitt for their helpful comments. Imad El Haddad is grateful to the Swiss National Science Foundation (SNSF) for the postdoctoral fellowship - SNSF_SAPMAV_200021_130169.

Edited by: L. M. Russell

\section{References}

Aiken, A. C., DeCarlo, P. F., Kroll, J. H., Worsnop, D. R., Huffman, J. A., Docherty, K. S., Ulbrich, I. M., Mohr, C., Kimmel, J. R., Sueper, D., Sun, Y., Zhang, Q., Trimborn, A., Northway, M., Ziemann, P. J., Canagaratna, M. R., Onasch, T. B., Alfarra, M. R., Prevot, A. S. H., Dommen, J., Duplissy, J., Metzger, A., Baltensperger, U., and Jimenez, J. L.: O/C and OM/OC ratios of primary, secondary, and ambient organic aerosols with highresolution time-of-flight aerosol mass spectrometry, Environ. Sci. Technol., 42, 4478-4485, doi:10.1021/es703009q, 2008.

Alfarra, M. R., Coe, H., Allan, J. D., Bowerb, K. N., Boudriesc, H., Canagaratna, M. R., Jimenez, J. L., Jayne, J. T., Garforth, A. A., Li, S.-M., and Worsnop, D. R.: Characterization of urban and rural organic particulate in the Lower Fraser Valley using two Aerodyne Aerosol Mass Spectrometers, Atmos. Environ. 38, 5745-5758, 2004.

Allan, J. D., Jimenez, J. L., Williams, P. I., Alfarra, M. R., Bower, K. N., Jayne, J. T., Coe, H., and Worsnop, D. R.: Quantitative sampling using an Aerodyne aerosol mass spectrometer: 1. Techniques of data interpretation and error analysis, J. Geophys. Res.Atmos., 108, 4090, doi:10.1029/2002JD002359, 2003.

Atkinson, R. and Arey, J.: Gas-phase tropospheric chemistry of biogenic volatile organic compounds: a review, Atmos. Environ., 37, S197-S219, doi:10.1016/S1352-2310(03)00391-1, 2003.

Baduel, C., Voisin, D., and Jaffrezo, J. L.: Comparison of analytical methods for Humic Like Substances (HULIS) measurements in atmospheric particles, Atmos. Chem. Phys., 9, 5949-5962, doi:10.5194/acp-9-5949-2009, 2009.

Baduel, C., Voisin, D., and Jaffrezo, J.-L.: Seasonal variations of concentrations and optical properties of water soluble HULIS collected in urban environments, Atmos. Chem. Phys., 10, 40854095, doi:10.5194/acp-10-4085-2010, 2010.

Baduel, C., Monge, M. E., Voisin, D., Jaffrezo, J. L., George, C., El Haddad, I., Marchand, N., and D'Anna, B.: Oxidation of atmospheric humic like substances by ozone: a kinetic and structural analysis approach, Environ. Sci. Technol., 45, 5238-5244, doi:10.1021/es200587z, 2011.

Bae, M.-S., Schauer, J. J., DeMinter, J. T., Turner, J. R., Smith, D., and Cary, R. A.: Validation of a semi-continuous instrument for elemental carbon and organic carbon using a thermal-optical method, Atmos. Environ., 38, 2885-2893, 2004.

Bahreini, R., Keywood, M. D., Ng, N. L., Varutbangkul, V., Gao, S., Flagan, R. C., Seinfeld, J. H., Worsnop, D. R., and Jimenez, J. L.: Measurements of Secondary Organic Aerosol from Oxidation of Cycloalkenes, Terpenes, and m-Xylene Using an Aerodyne Aerosol Mass Spectrometer, Environ. Sci. Technol., 39, 56745688, doi:10.1021/es048061a, 2005.

Bahreini, R., Middlebrook, A. M., de Gouw, J. A., Warneke, C., Trainer, M., Brock, C. A., Stark, H., Brown, S. S., Dube, W. P., Gilman, J. B., Hall, K., Holloway, J. S., Kuster, W. C., Perring, A. E., Prevot, A. S. H., Schwarz, J. P., Spackman, J. R., Szidat, S., 
Wagner, N. L., Weber, R. J., Zotter, P., and Parrish, D. D.: Geophys. Res. Let., 39, L06805, doi:10.1029/2011GL050718, 2012.

Cappa, C. D. and Jimenez, J. L.: Quantitative estimates of the volatility of ambient organic aerosol, Atmos. Chem. Phys., 10, 5409-5424, doi:10.5194/acp-10-5409-2010, 2010.

Canagaratna, M. R., Jayne, J. T., Ghertner, D. A., Herndon, S., Shi, Q. Jimenez, J. L., Silva, P. J., Williams, P., Lanni, T., Drewnick, F., Demerjian, K. L., Kolb, C. E., and Worsnop, D. R.: Chase Studies of Particulate Emissions from in-use New York City Vehicles, Aerosol Sci. Technol., 38, 555-573, 2004.

Canagaratna, M. R., Jayne, J. T., Jimenez, J. L., Allan, J. D., Alfarra, M. R., Zhang, Q., Onasch, T. B., Drewnick, F., Coe, H., Middlebrook, A. M., Delia, A., Williams, L. R., Trimborn, A. M., Northway, M. J., DeCarlo, P. F., Kolb, C. E., Davidovits, P., and Worsnop, D. R.: Chemical and microphysical characterization of ambient aerosols with the Aerodyne aerosol mass spectrometer, Mass Spectrom. Rev., 26, 185-222, 2007.

Cavalli, F., Viana, M., Yttri, K. E., Genberg, J., and Putaud, J.-P.: Toward a standardised thermal-optical protocol for measuring atmospheric organic and elemental carbon: the EUSAAR protocol, Atmos. Meas. Tech., 3, 79-89, doi:10.5194/amt-3-79-2010, 2010.

Chirico, R., Prevot, A. S. H., DeCarlo, P. F., Heringa, M. F., Richter, R., Weingartner, E., and Baltensperger, U.: Aerosol and Trace Gas Vehicle Emission Factors Measured in a Tunnel Using an Aerosol Mass Spectrometer and other On-line Instrumentation, Atmos. Environ., 45, 2182-2192, doi:10.1016/j.atmosenv.2011.01.069, 2011.

Chacon-Madrid, H. J. and Donahue, N. M.: Fragmentation vs. functionalization: chemical aging and organic aerosol formation, Atmos. Chem. Phys., 11, 10553-10563, doi:10.5194/acp11-10553-2011, 2011.

Chen, S., Brune, W. H., Lambe, A. T., Davidovits, P., and Onasch, T. B.: Modeling organic aerosol from the oxidation of $\alpha$-pinene in a Potential Aerosol Mass (PAM) chamber, Atmos. Chem. Phys., 13, 5017-5031, doi:10.5194/acp-13-5017-2013, 2013.

Crippa, M., El Haddad, I., Slowik, J. G., DeCarlo, P. F., Mohr, C., Heringa, M. F., Chirico, R., Marchand, N., Sciare, J., Baltensperger, U., and Prevot, A. S. H.: Identification of Marine and Continental Aerosol Sources in Paris Using High Resolution Mass Spectrometry, J. Geophys. Res. Atmos., 118, 1-19, doi:10.1029/jgrd.50151, 2013.

DeCarlo, P. F., Dunlea, E. J., Kimmel, J. R., Aiken, A. C., Sueper, D., Crounse, J., Wennberg, P. O., Emmons, L., Shinozuka, Y., Clarke, A., Zhou, J., Tomlinson, J., Collins, D. R., Knapp, D., Weinheimer, A. J., Montzka, D. D., Campos, T., and Jimenez, J. L.: Fast airborne aerosol size and chemistry measurements above Mexico City and Central Mexico during the MILAGRO campaign, Atmos. Chem. Phys., 8, 4027-4048, doi:10.5194/acp-84027-2008, 2008.

de Gouw, J. A. and Warneke, C.: Measurements of volatile organic compounds in the Earth's atmosphere using protontransferreaction mass spectrometry, Mass Spec. Rev., 26, 223257, 2007

de Gouw, J. A., Middlebrook, A. M., Warneke, C., Goldan, P. D., Kuster, W. C., Roberts, J. M., Fehsenfeld, F. C., Worsnop, D. R., Canagaratna, M. R., Pszenny, A. A. P., Keene, W. C., Marchewka, M., Bertman, S. B., and Bates, T. S.: Budget of organic carbon in a polluted atmosphere: Results from the New
England Air Quality Study in 2002, J. Geophys. Res., 110, D16305, doi:10.1029/2004JD005623, 2005.

Donahue, N. M., Robinson, A. L., andPandis, S. N.: Atmospheric organic particulate matter: From smoke to secondary organic aerosol, Atmos. Environ., 43, 94-106, 2009.

Donahue, N. M., Kroll, J. H., Pandis, S. N., and Robinson, A. L.: A two-dimensional volatility basis set - Part 2: Diagnostics of organic-aerosol evolution, Atmos. Chem. Phys., 12, 615-634, doi:10.5194/acp-12-615-2012, 2012.

Drewnick, F., Hings, S. S., DeCarlo, P., Jayne, J. T., Gonin, M., Fuhrer, K., Weimer, S., Jimenez, J. L., Demerjian, K. L., Borrmann, S., and Worsnop, D. R.: A new time-of-flight aerosol mass spectrometer (TOF-AMS) - Instrument description and first field deployment, Aerosol Sci. Tech., 39, 637-658, 2005.

Duhl, T. R., Helmig, D., and Guenther, A.: Sesquiterpene emissions from vegetation: a review, Biogeosciences, 5, 761-777, doi:10.5194/bg-5-761-2008, 2008.

Eddingsaas, N. C., Loza, C. L., Yee, L. D., Seinfeld, J. H., and Wennberg, P. O.: $\alpha$-pinene photooxidation under controlled chemical conditions - Part 1: Gas-phase composition in low- and high-NOx environments, Atmos. Chem. Phys., 12, 6489-6504, doi:10.5194/acp-12-6489-2012, 2012a.

Eddingsaas, N. C., Loza, C. L., Yee, L. D., Chan, M., Schilling, K. A., Chhabra, P. S., Seinfeld, J. H., and Wennberg, P. O.: $\alpha$-pinene photooxidation under controlled chemical conditions - Part 2: SOA yield and composition in low- and high-NOx environments, Atmos. Chem. Phys., 12, 7413-7427, doi:10.5194/acp-12-74132012, 2012b.

Ehn, M., Kleist, E., Junninen, H., Petäjä, T., Lönn, G., Schobesberger, S., Dal Maso, M., Trimborn, A., Kulmala, M., Worsnop, D. R., Wahner, A., Wildt, J., and Mentel, Th. F.: Gas phase formation of extremely oxidized pinene reaction products in chamber and ambient air, Atmos. Chem. Phys., 12, 5113-5127, doi:10.5194/acp-12-5113-2012, 2012.

El Haddad, I., Marchand, N., Wortham, H., Piot, C., Besombes, J.L., Cozic, J., Chauvel, C., Armengaud, A., Robin, D., and Jaffrezo, J.-L.: Primary sources of $\mathrm{PM}_{2.5}$ organic aerosol in an industrial Mediterranean city, Marseille, Atmos. Chem. Phys., 11, 2039-2058, doi:10.5194/acp-11-2039-2011, 2011a.

El Haddad, I., Marchand, N., Temime-Roussel, B., Wortham, H., Piot, C., Besombes, J.-L., Baduel, C., Voisin, D., Armengaud, A., and Jaffrezo, J.-L.: Insights into the secondary fraction of the organic aerosol in a Mediterranean urban area: Marseille, Atmos. Chem. Phys., 11, 2059-2079, doi:10.5194/acp-11-20592011, $2011 b$.

El Haddad, I., Marchand, N., D’Anna , B., Jaffrezo, J.-L., and Wortham, H.: Functional group composition of organic aerosol from combustion emissions and secondary processes at two contrasted urban environments, Atmos. Environ., 75, 308-320, doi:10.1016/j.atmosenv.2013.04.019, 2013.

Favez, O., El Haddad, I., Piot, C., Boréave, A., Abidi, E., Marchand, N., Jaffrezo, J.-L., Besombes, J.-L., Personnaz, M.-B., Sciare, J., Wortham, H., George, C., and D'Anna, B.: Inter-comparison of source apportionment models for the estimation of wood burning aerosols during wintertime in an Alpine city (Grenoble, France), Atmos. Chem. Phys., 10, 5295-5314, doi:10.5194/acp-10-52952010, 2010.

Hallquist, M., Wenger, J. C., Baltensperger, U., Rudich, Y., Simpson, D., Claeys, M., Dommen, J., Donahue, N. M., George, 
C., Goldstein, A. H., Hamilton, J. F., Herrmann, H., Hoffmann, T., Iinuma, Y., Jang, M., Jenkin, M. E., Jimenez, J. L., Kiendler-Scharr, A., Maenhaut, W., McFiggans, G., Mentel, Th. F., Monod, A., Prévôt, A. S. H., Seinfeld, J. H., Surratt, J. D., Szmigielski, R., and Wildt, J.: The formation, properties and impact of secondary organic aerosol: current and emerging issues, Atmos. Chem. Phys., 9, 5155-5236, doi:10.5194/acp-9-51552009, 2009.

Heald, C. L., Kroll, J. H., Jimenez, J. L., Docherty, K. S., DeCarlo, P. F., Aiken, A. C., Chen, Q., Martin, S. T., Farmer, D. K., and Artaxo, P.: A simplified description of the evolution of organic aerosol composition in the atmosphere. Geophys. Res. Lett., 37, L08803, doi:10.1029/2010GL042737, 2010.

Hodzic, A., Jimenez, J. L., Prévôt, A. S. H., Szidat, S., Fast, J. D., and Madronich, S.: Can 3-D models explain the observed fractions of fossil and non-fossil carbon in and near Mexico City?, Atmos. Chem. Phys., 10, 10997-11016, doi:10.5194/acp10-10997-2010, 2010.

Jaoui, M., Kleindienst, T. E., Lewandowski, M., Offenberg, J. H., and Edney, E. O.: Identification and quantification of aerosol polar oxygenated compounds bearing carboxylic or hydroxyl groups, 2. Organic tracer compounds from monoterpenes, Environ. Sci. Technol., 39, 5661-5673, doi:10.1021/es048111b, 2005.

Jimenez, J. L., Canagaratna, M. R., Donahue, N. M., Prevot, A. S. H., Zhang, Q., Kroll, J. H., DeCarlo, P. F., Allan, J. D., Coe, H., Ng, N. L., Aiken, A. C., Docherty, K. S., Ulbrich, I. M., Grieshop, A. P., Robinson, A. L., Duplissy, J., Smith, J. D., Wilson, K. R., Lanz, V. A., Hueglin, C., Sun, Y. L., Tian, J., Laaksonen, A., Raatikainen, T., Rautiainen, J., Vaattovaara, P., Ehn, M., Kulmala, M., Tomlinson, J. M., Collins, D. R., Cubison, M. J., Dunlea, E. J., Huffman, J. A., Onasch, T. B., Alfarra, M. R., Williams, P. I., Bower, K., Kondo, Y., Schneider, J., Drewnick, F., Borrmann, S., Weimer, S., Demerjian, K., Salcedo, D., Cottrell, L., Griffin, R., Takami, A., Miyoshi, T., Hatakeyama, S., Shimono, A., Sun, J. Y., Zhang, Y. M., Dzepina, K., Kimmel, J. R., Sueper, D., Jayne, J. T., Herndon, S. C., Trimborn, A. M., Williams, L. R., Wood, E. C., Middlebrook, A. M., Kolb, C. E., Baltensperger, U., and Worsnop, D. R.: Evolution of organic aerosols in the atmosphere, Science, 326, 1525-1529, 2009.

Kleindienst, T. E., Jaoui, M., Lewandowski, M., Offenberg, J. H., Lewis, C. W., Bhave, P. V., and Edney, E. O.: Estimates of the contributions of biogenic and anthropogenic hydrocarbons to secondary organic aerosol at a southeastern US location, Atmos. Environ., 41, 8288-8300, 2007.

Kroll, J. H., Ng, N. L., Murphy, S. M., Flagan, R. C., and Seinfeld, J. H.: Secondary organic aerosol formation from isoprene photooxidation, Environ. Sci. Technol., 40, 1869-1877, 2006.

Kroll, J. H., Smith, J. D., Che, D. L., Kessler, S. H., Worsnop, D. R., and Wilson, K. R.: Measurement of fragmentation and functionalization pathways in the heterogeneous oxidation of oxidized organic aerosol, Phys. Chem. Chem. Phys., 11, 8005-8014, doi:10.1039/b905289e, 2009.

Lang-Yona, N., Rudich, Y., Mentel, Th. F., Bohne, A., Buchholz, A., Kiendler-Scharr, A., Kleist, E., Spindler, C., Tillmann, R., and Wildt, J.: The chemical and microphysical properties of secondary organic aerosols from Holm Oak emissions, Atmos. Chem. Phys., 10, 7253-7265, doi:10.5194/acp-10-7253-2010, 2010 .
Lanz, V. A., Alfarra, M. R., Baltensperger, U., Buchmann, B., Hueglin, C., and Prévôt, A. S. H.: Source apportionment of submicron organic aerosols at an urban site by factor analytical modelling of aerosol mass spectra, Atmos. Chem. Phys., 7, 15031522, doi:10.5194/acp-7-1503-2007, 2007.

Leaitch, W. R., MacDonald, A. M., Brickell, P. C., Liggio, J., Sjostedt, S. J., Vlasenko, A., Bottenheim, J. W., Huang, L., Li, S.M., Liu, P. S. K., Toom-Sauntry, D., Hayden, K. A., Sharma, S., Shantz, N. C., Wiebe, H. A., Zhang, W., Abbatt, J. P. D., Slowik, J. G., Chang, R. Y.-W., Russell, L. M., Schwartz, R. E., Takahama, S., Jayne, J. T., and Ng, N. L.: Temperature response of the submicron organic aerosol from temperate forests, Atmos. Environ., 45, 6696-6704, doi:10.1016/j.atmosenv.2011.08.047, 2011

Lee, A. K. Y., Hayden, K. L., Herckes, P., Leaitch, W. R., Liggio, J., Macdonald, A. M., and Abbatt, J. P. D.: Characterization of aerosol and cloud water at a mountain site during WACS 2010: secondary organic aerosol formation through oxidative cloud processing, Atmos. Chem. Phys., 12, 7103-7116, doi:10.5194/acp-12-7103-2012, 2012.

Liakakou, E., Bonsang, B., Williams, J., Kalivitis, N., Kanakidou, M., and Mihalopoulos, N.: C-2-C-8 NMHCs over the Eastern Mediterranean: Seasonal variation and impact on regional oxidation chemistry, Atmos. Environ., 43, 5611-5621, 2009.

Liggio, J., Li, S.-M., Vlasenko, A., Sjostedt, S., Chang, R., Shantz, N., Abbatt, J., Slowik, J. G., Bottenheim, J. W., Brickell, P. C., Stroud, C., and Leaitch, W. R.: Primary and Secondary Organic Aerosols in Urban Air Masses Intercepted at a Rural Site, J. Geophys. Res., 115, D21305, doi:10.1029/2010JD014426, 2010.

Lindinger, W., Hansel, A., and Jordan, A.: On-line monitoring of volatile organic compounds at pptv levels by means of protontransfer-reaction mass spectrometry (PTR-MS) - Medical applications, food control and environmental research, Int. J Mass. Spectrom., 173, 191-241, 1998.

Liu, Y., El Zein, A., Siekmann, F., Salque, G., El Haddad, I., Temime-Roussel, B., Voisin, D., Thissen, R., and Monod, A.: Oligomer and SOA formation through atmospheric aqueous phase processing of methacrolein and methyl vinyl ketone, Atmos. Environ., 49, 123-129, 2012.

Middlebrook, A. M., Bahreini, R., Jimenez, J. L., and Canagaratna, M. R.: Evaluation of Composition-Dependent Collection Efficiencies for the Aerodyne Aerosol Mass Spectrometer using Field Data, Aerosol Sci. Technol., 46, 258-271, doi:10.1080/02786826.2011.620041, 2012.

Minguillón, M. C., Perron, N., Querol, X., Szidat, S., Fahrni, S. M., Alastuey, A., Jimenez, J. L., Mohr, C., Ortega, A. M., Day, D. A., Lanz, V. A., Wacker, L., Reche, C., Cusack, M., Amato, F., Kiss, G., Hoffer, A., Decesari, S., Moretti, F., Hillamo, R., Teinilä, K., Seco, R., Peñuelas, J., Metzger, A., Schallhart, S., Müller, M., Hansel, A., Burkhart, J. F., Baltensperger, U., and Prévôt, A. S. H.: Fossil versus contemporary sources of fine elemental and organic carbonaceous particulate matter during the DAURE campaign in Northeast Spain, Atmos. Chem. Phys., 11, 12067-12084, doi:10.5194/acp-11-12067-2011, 2011.

Mohr, C., DeCarlo, P. F., Heringa, M. F., Chirico, R., Slowik, J. G., Richter, R., Reche, C., Alastuey, A., Querol, X., Seco, R., Peñuelas, J., Jiménez, J. L., Crippa, M., Zimmermann, R., Baltensperger, U., and Prévôt, A. S. H.: Identification and quantification of organic aerosol from cooking and other sources in Barcelona using aerosol mass spectrometer data, Atmos. Chem. 
Phys., 12, 1649-1665, doi:10.5194/acp-12-1649-2012, 2012.

Müller, L., Reinnig, M.-C., Naumann, K. H., Saathoff, H., Mentel, T. F., Donahue, N. M., and Hoffmann, T.: Formation of 3-methyl1,2,3-butanetricarboxylic acid via gas phase oxidation of pinonic acid - a mass spectrometric study of SOA aging, Atmos. Chem. Phys., 12, 1483-1496, doi:10.5194/acp-12-1483-2012, 2012.

Ng, N. L., Kroll, J. H., Keywood, M. D., Bahreini, R., Varutbangkul, V., Flagan, R. C., Seinfeld, J. H., Lee, A., and Goldstein, A. H.: Contribution of first- versus second-generation products to secondary organic aerosols formed in the oxidation of biogenic hydrocarbons, Environ. Sci. Technol., 40, 2283-2297, doi:10.1021/es052269u, 2006.

Paatero, P. and Tapper, U.: Positive matrix factorization: a nonnegative factor model with optimal utilization of error estimates of data values, Environmetrics, 5, 111-126, 1994.

Parra, R., Gasso, S., and Baldasano, J. M.: Estimating the biogenic emissions of non-methane volatile organic compounds from the North Western Mediterranean vegetation of Catalonia, Spain, Sci. Total Environ., 329, 241-259, 2004.

Pfaffenberger, L., Barmet, P., Slowik, J. G., Praplan, A. P., Dommen, J., Prévôt, A. S. H., and Baltensperger, U.: The link between organic aerosol mass loading and degree of oxygenation: an $\alpha$ pinene photooxidation study, Atmos. Chem. Phys., 13, 64936506, doi:10.5194/acp-13-6493-2013, 2013.

Piot, C., Jaffrezo, J.-L., Cozic, J., Pissot, N., El Haddad, I., Marchand, N., and Besombes, J.-L.: Quantification of levoglucosan and its isomers by High Performance Liquid Chromatography Electrospray Ionization tandem Mass Spectrometry and its applications to atmospheric and soil samples, Atmos. Meas. Tech., 5, 141-148, doi:10.5194/amt-5-141-2012, 2012.

Sakulyanontvittaya, T., Duhl, T., Wiedinmyer, C., Helmig, D., Matsunaga, S., Potosnak, M., Milford, J., and Guenther, A.: Monoterpene and Sesquiterpene Emission Estimates for the United States, Environ. Sci. Technol., 42, 1623-1629, doi:10.1021/es702274e, 2008.

Slowik, J. G., Stroud, C., Bottenheim, J. W., Brickell, P. C., Chang, R. Y.-W., Liggio, J., Makar, P. A., Martin, R. V., Moran, M. D., Shantz, N. C., Sjostedt, S. J., van Donkelaar, A., Vlasenko, A., Wiebe, H. A., Xia, A. G., Zhang, J., Leaitch, W. R., and Abbatt, J. P. D.: Characterization of a large biogenic secondary organic aerosol event from eastern Canadian forests, Atmos. Chem. Phys., 10, 2825-2845, doi:10.5194/acp-10-2825-2010, 2010.

Schauer, J. J., Kleeman, M. J., Cass, G. R., and Simoneit, B. R. T.: Measurement of Emissions from Air Pollution Sources. 2. C1 through C30 Organic Compounds from Medium Duty Diesel Trucks, Environ. Sci. Technol., 33, 1578-1587, doi:10.1021/es980081n, 1999.

Schmid, H., Laskus, L., Jurgen Abraham, H., Baltensperger, U., Lavanchy, V., Bizjak, M., Burba, P., Cachier, H., Crow, D., Chow, J., Gnauk, T., Even, A., ten Brink, H. M., Giesen, K.-P., Hitzenberger, R., Hueglin, C., Maenhaut, W., Pio, C., Carvalho, A., Putaud, J.-P., Toom-Sauntry, D., and Puxbaum, H.: Results of the "carbon conference" international aerosol carbon round robin test stage I, Atmos. Environ., 35, 2111-2121, 2001.
Sjostedt, S. J., Slowik, J. G., Brook, J. R., Chang, R. Y.-W., Mihele, C., Stroud, C. A., Vlasenko, A., and Abbatt, J. P. D.: Diurnally resolved particulate and VOC measurements at a rural site: indication of significant biogenic secondary organic aerosol formation, Atmos. Chem. Phys., 11, 5745-5760, doi:10.5194/acp-11-57452011, 2011.

Steinbrecher, R., Smiatek, G., Koble, R., Seufert, G., Theloke, J., Hauff, K., Ciccioli, P., Vautard, R., and Curci, G.: Intra- and inter-annual variability of VOC emissions from natural and seminatural vegetation in Europe and neighbouring countries, Atmos. Environ., 43, 1380-1391, 2009.

Szidat, S.: Radiocarbon analysis of carbonaceous aerosols: recent developments, CHIMIA, 63, 157-161, doi:10.2533/chimia.2009.157, 2009.

Szmigielski, R., Surratt, J. D., Gomez-Gonzalez, Y., Van der Veken, P., Kourtchev, I., Vermeylen, R., Blockhuys, F., Jaoui, M., Kleindienst, T. E., Lewandowski, M., Offenberg, J. H., Edney, E. O., Seinfeld, J. H., Maenhaut, W., and Claeys, M.: 3-methyl1,2,3-butanetricarboxylic acid: An atmospheric tracer for terpene secondary organic aerosol, Geophys. Res. Lett., 34, L24811, doi:10.1029/2007GL031338, 2007.

Ulbrich, I. M., Canagaratna, M. R., Zhang, Q., Worsnop, D. R., and Jimenez, J. L.: Interpretation of organic components from Positive Matrix Factorization of aerosol mass spectrometric data, Atmos. Chem. Phys., 9, 2891-2918, doi:10.5194/acp-9-2891-2009, 2009.

Vlasenko, A., Slowik, J. G., Bottenheim, J. W., Brickell, P. C., Chang, R. Y.-W., Macdonald, A. M., Shantz, N. C., Sjostedt, S. J., Wiebe, H. A., Leaitch, W. R., and Abbatt, J. P. D.: Measurements of VOCs by proton transfer reaction mass spectrometry at a rural Ontario site: Sources and correlation to aerosol composition, J. Geophys. Res., 114, D21305, doi:10.1029/2009JD012025, 2009.

Volkamer, R., Jimenez, J. L., San Martini, F., Dzepina, K., Zhang, Q., Salcedo, D., Molina, L. T., Worsnop, D. R., and Molina, M. J.: Secondary Organic Aerosol Formation from Anthropogenic Air Pollution: Rapid and Higher than Expected, Geophys. Res. Lett., 33, L17811, doi:10.1029/2006GL026899, 2006.

Watson, J. G., Robinson, N. F., Fujita, E. M., Chow, J. C., Pace, T. G., Lewis, C., and Coulter, T.: CMB8 Applications and Validation Protocol for PM2.5 and VOCs, US EPA, USA, 1998.

Zhang, Q., Alfarra, M. R., Worsnop, D. R., Allan, J. D., Coe, H., Canagaratna, M. R., and Jimenez, J. L.: Deconvolution and quantification of hydrocarbon-like and oxygenated organic aerosols based on aerosol mass spectrometry, Environ. Sci. Technol., 39, 4938-4952, 2005. 